\title{
Diagnostic Algorithms in Renal Biopsy Interpretation Along with Case Samples
}

\author{
Şafak Güçer \\ Hacettepe University, Faculty of Medicine Pediatric Pathology Unit Ankara \\ Turkey
}

\section{Introduction}

Despite significant advances in molecular analytical techniques impacting the diagnostic approach to the renal biopsy a systematic study of morphological findings is still a magic tool to provide valuable diagnostic and prognostic information in patients with renal disease in the light of history and laboratory findings.

\section{Approach to renal biopsy interpretation with algorithms}

Kidney has three main histological compartments including glomerular, vascular and tubulointerstitial. First, an approach should be performed to localize in which department the main injury occurs and to recognize the severity and extent of the renal injury in each department. Then, the type of injury is to be assessed such as active versus chronic. Active lesions includes cellular proliferation, crescents, edema, necrosis and acute inflammation while chronic lesions represent fibrosing conditions such as fibrous crescents, interstitial fibrosis, glomerulosclerosis, tubular atrophy or vascular sclerosis. (Walker, 2004, 2009; Kretzler, 2002; Fogo, 2003)

\subsection{The native kidney biopsy lesions}

\subsubsection{Glomerular lesions}

\subsubsection{No or minimal hypercellularity (Figure 1.)}

The first step is to determine whether there is hypercellularity or not. No or minimal hypercellularity offers usually a limited differential diagnosis. Then, in such cases further investigations with immunofluorescence (IF) and electron microscopy(EM) are needed along with a detailed clinical history. If glomerular capillaries are abnormal three main categories are defined; glomerular capillary wall thickening, sclerosis/capillary wall collapse and luminal occlusion(Furness,2000;Lajoie\&Silva,1996).

If the patient has nephrotic syndrome three main diagnosis are considered ; minimal change disease, membranous GN(early stage ) and also amyloidosis in which amyloid deposits can be very subtle to detect on light microscopy. However, these disorders can be easily differentiated by immunofluorescence and ultrastructural microscopic findings.

Minimal change diseases(MCD) is the most common cause of idiopathic nephrotic syndrome and characterized by absence of pathologic changes by light microscopy but 
diffuse effacement of foot processes of podocytes by EM. (Figs. 2,3) It is usually a primary disease but it may be secondary to malignant diseases and nonsteroidal anti-inflammatory drugs(Mubarak,2011,Zhang,2011). Proteinuria is generally massive, selective and mostly of abrupt onset.

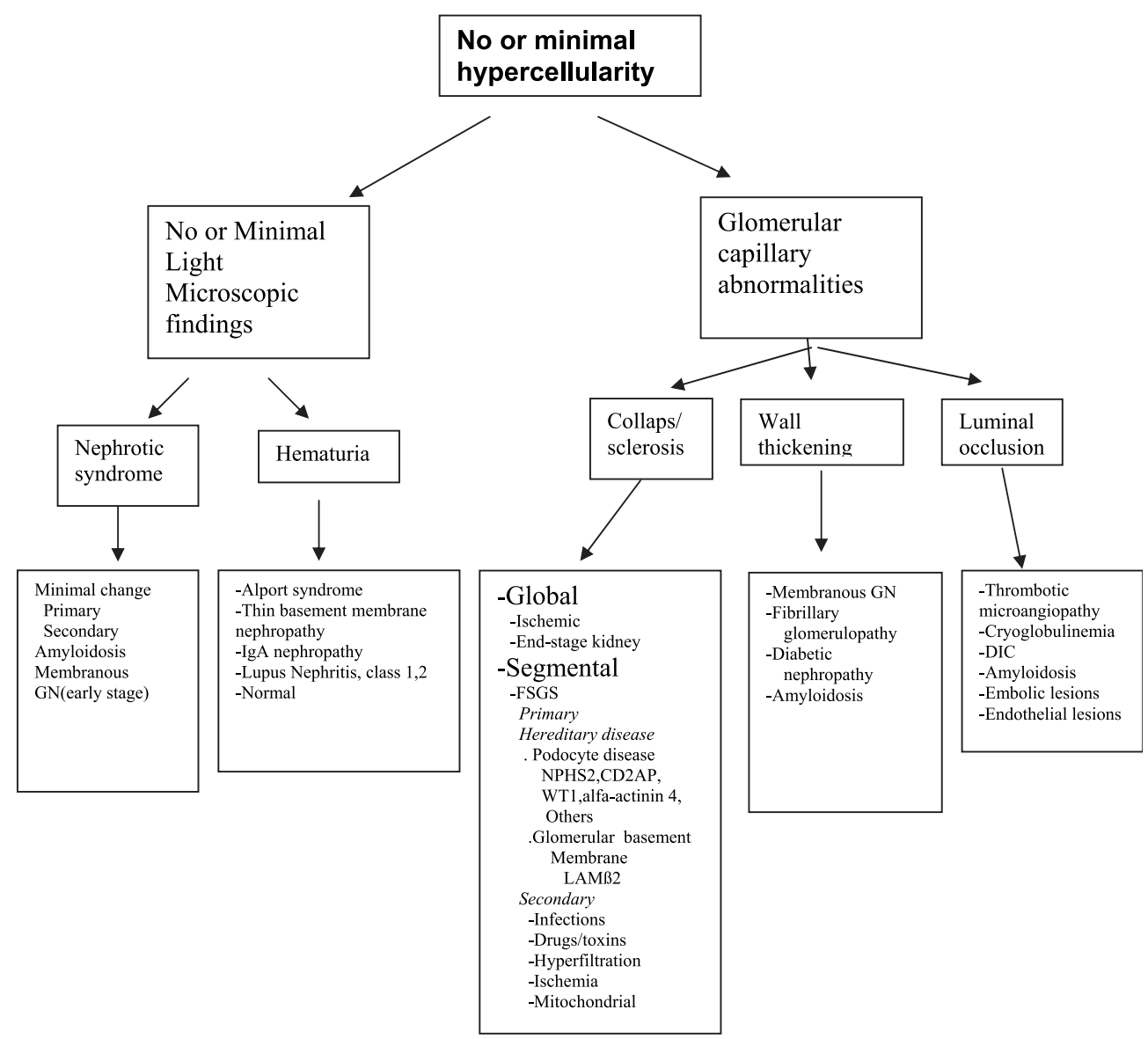

Fig. 1. An algorithm for interpretation of glomerular morphological changes with no or minimal hypercellularity.(GN:Glomerulonephritis, FSGS; Focal segmental glomerulosclerosis, NPHS2;(Podocin), CD2AP; CD-associated protein, WT1; Wilms' tumor1, LAMß2;Laminin B2, DIC; disseminated intravascular coagulation)

\section{CASE 1.}

A 5 year-old-male was admitted to the hospital with the complaints of swelling of eyelids, legs and fatigue lasting for 2 months.

No family history for kidney disease or consanguinity between parents.

On physical exam: Blood pressure:100/60 $\mathrm{mmHg}$, pretibial 4(+) pitting edema was noted. Laboratory findings: Complete blood count and electrolytes were normal , ESR $33 \mathrm{~mm} / \mathrm{hr}$ 
BUN $10 \mathrm{mg} / \mathrm{dl}, \mathrm{Cr}: 0.3 \mathrm{~m} \mathrm{~g} / \mathrm{dl}$, Total protein/Albumin: 4.9/2 g/dl

Urinalysis: Density 1025, Proteinuria $80 \mathrm{mg} / \mathrm{m} 2 / \mathrm{hr}$, no glucose, sediment: 3-4 white blood cells.

Serum C3 ,C4 levels, ANA, Anti-DNA, viral markers were all normal.

Renal ultrasonography revealed unremarkable findings.

Renal biopsy diagnosis: Minimal change disease (Figs. 2,3)

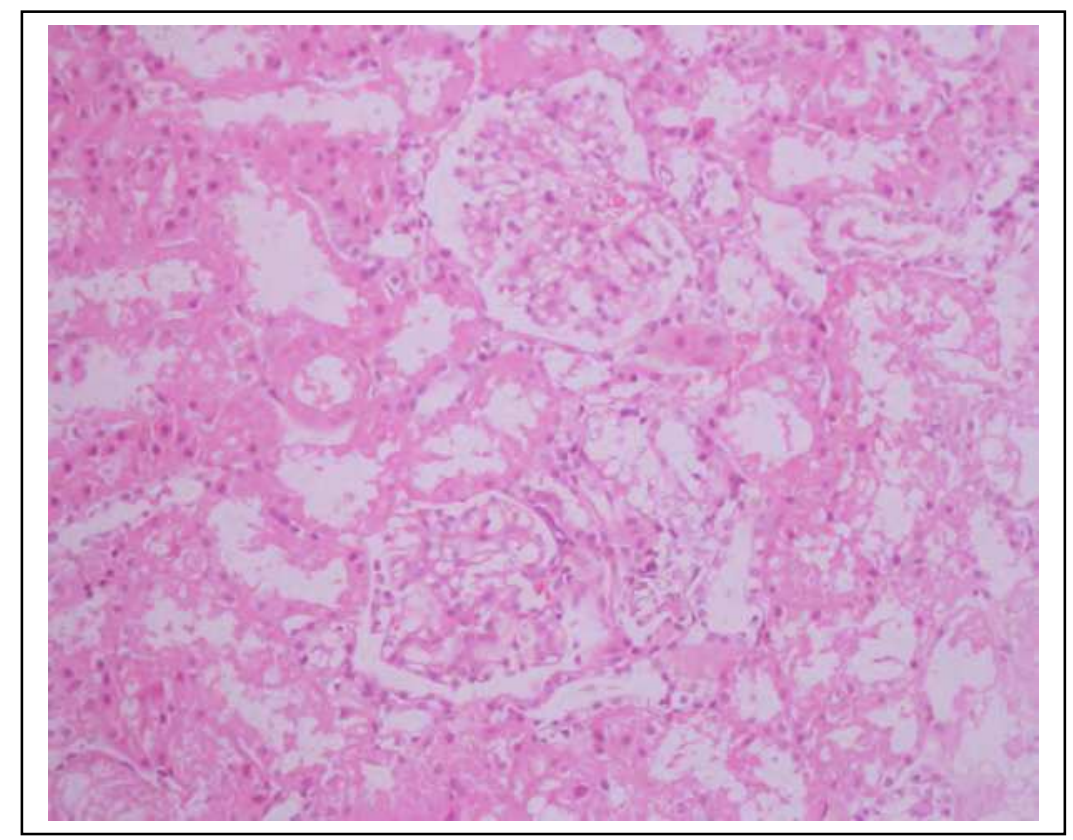

Fig. 2. Minimal change disease. Note the patent glomerular capillaries with normal amount of matrix and mesangial cells.(HEx100)

In cases with hematuria and glomerular basement membrane(GBM) thinning one should consider first Alport syndrome (AS) or thin basement membrane nephropathy(TBMN). Diagnosis of thinning should be made by comparison of age-matched controls. A cut-off value has been reported $250 \mathrm{~nm}$ in adults in most series. However, care must be taken to diagnose TBMN in children since GBM thickening increases with age(Kashtan, 2009).

A thinned GBM may be an early lesion in Alport syndrome. Children with Alport syndrome may show only diffuse GBM attenuation, making differentiation from TBMN a challenge.

However, in full-blown cases with AS there is also characteristic thickening of the glomerular basement membrane with splitting of the lamina densa, electron lucent areas and electron dense particles detected by EM. (Figs. 4,5)A progressive, high-frequency sensorineural deafness frequently detectable by audiometry in later childhood in boys with X-linked AS and both boys and girls with autosomal recessive AS and anterior lenticonus or perimacular retinal flecks are other characteristics of AS (Savige, 2003; Haas, 2009). 
Thinning of lamina densa of GBM can be seen in normal children, IgA nephropathy, minimal change disease and in some forms of lupus nephritis. However, thinning in these disorders is mostly segmental whereas there is a diffuse involvement in patients with TBMN.

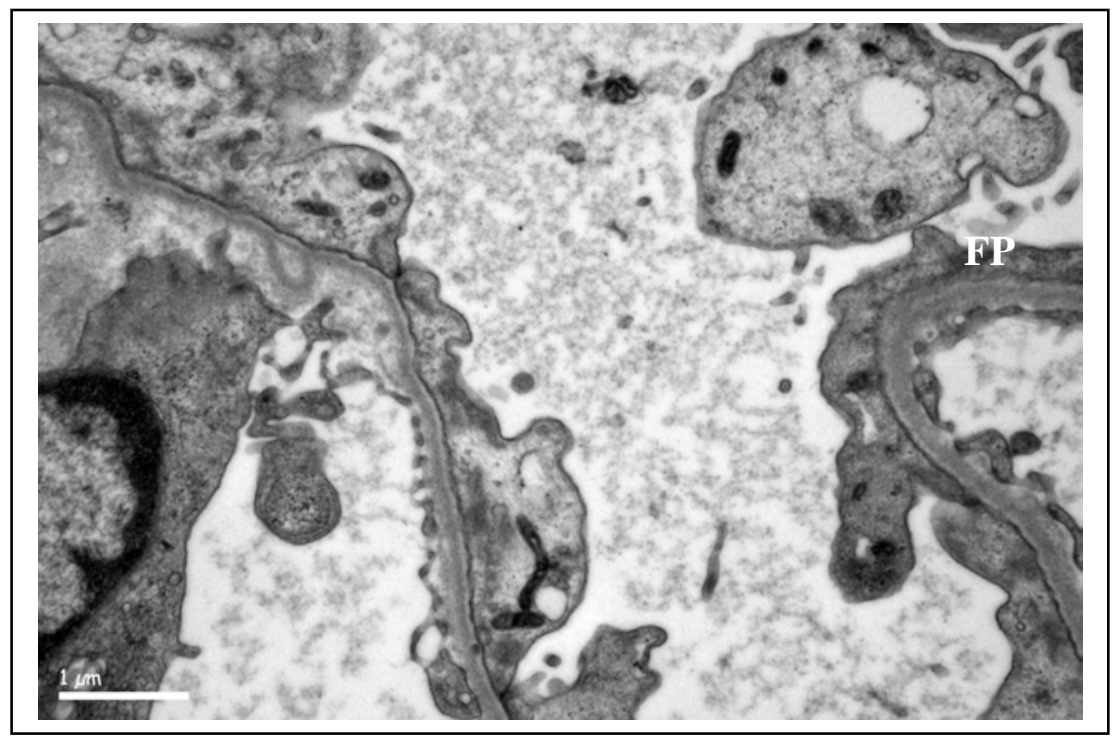

Fig. 3. Minimal change disease. Electron micrograph shows diffuse effacement of foot processes(FP).(Uranyl acetate and lead citratex10000)

A thickened GBM can be detected as a major feature in several glomerular diseases including membranous GN, membranoproliferative(mesangiocapillary) GN , fibrillary GN and diabetic nephropathy, thrombotic microangiopathy, Alport syndrome or transplant glomerulopathy. Aforementioned first three disorders have typical immunofluorescence microscopic findings while IF is expected to be negative in the others.

\section{CASE 2.}

A 7 year-old-male was admitted to the hospital with the complaints of dysuria and hearing problems. He had been suffering these symptoms for two years.

No consanguinity between parents but his grandmother died of chronic renal failure of unknown etiology.

Physical examination was unremarkable except a sensorineural hearing loss. Blood pressure:100/60 $\mathrm{mmHg}$

Laboratory findings: Complete blood count and electrolytes were normal.

BUN $17.3 \mathrm{mg} / \mathrm{dl}, \mathrm{Cr}: 0.64 \mathrm{mg} / \mathrm{dl}$, Total protein/Albumin: 6.9/3.6 g/dl

Urinalysis: Density 1025, Proteinuria $10 \mathrm{mg} / \mathrm{m} 2 / \mathrm{hr}$, no glucose, sediment: abundant red blood cells.

Serum C3 ,C4 levels, ANA, Anti-DNA,viral markers were all normal.

Renal USG revealed normal size and echogenicity in kidneys.

Renal biopsy diagnosis: Alport syndrome (Figures 4,5) 


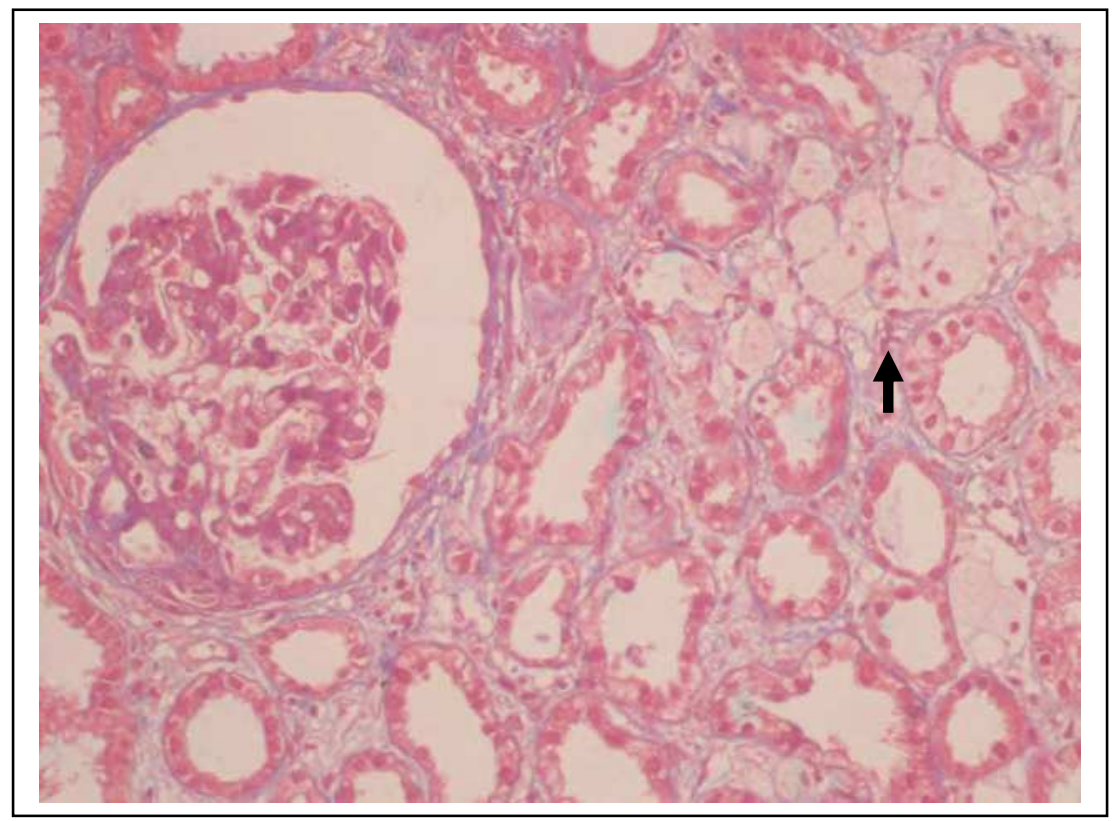

Fig. 4. Alport syndrome. Note mesangial matrix increment, adhesion to Bowman capsule, interstitial foam cells (arrow) and fibrosis in the interstitium. Trichromex200.

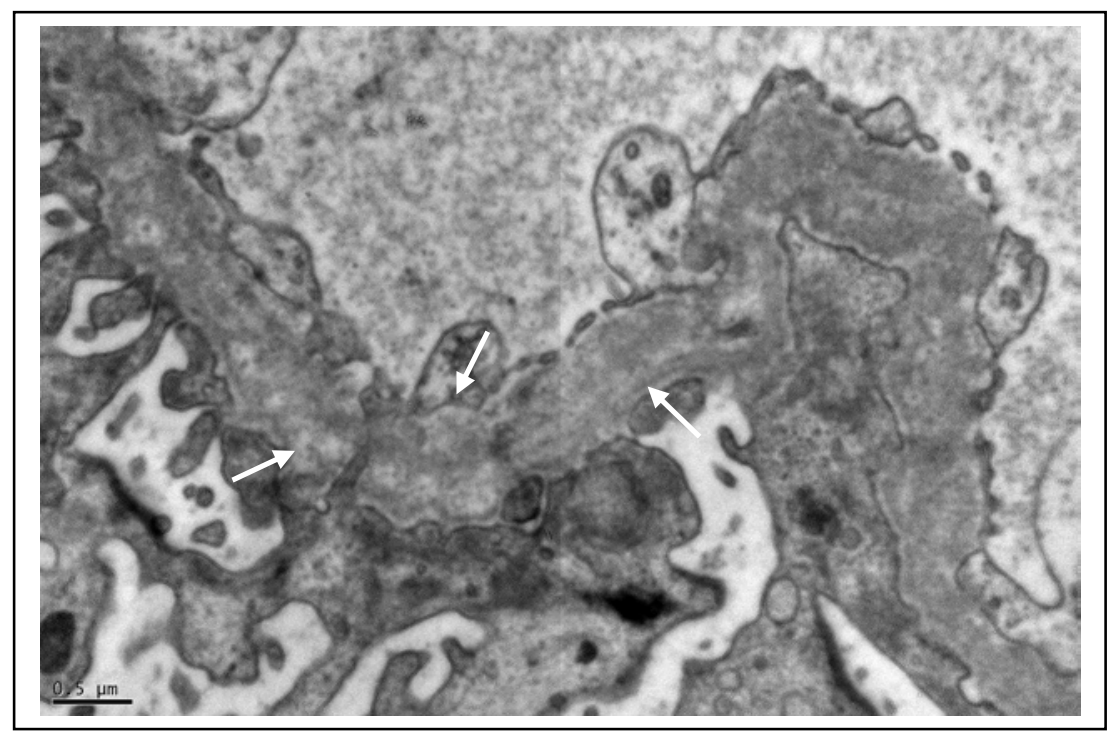

Fig. 5. Alport syndrome. Electron micrograph demonstrating thickening, irregular contours of glomerular basement membrane, splitting lamina densa and several electron dense granules(arrows). Uranyl acetate-Lead citrate x 30000 . 
In some cases, one may encounter unusual or rare lesions such as foamy podocytes and/or tubules with various storage material ,foam cells within the glomerular tuft or heavily deposited collagen Type III material detected by EM. These storage materials can be diagnostic clues of specific metabolic or hereditary diseases. Fabry disease is the most common which is characterized by foamy podocytes with myelin body type inclusions by EM in podocytes, corneal epithelium, endothelial cells, etc. (Fogo,2003).

If glomerular capillary collapse or sclerosis is the main lesion it can be global or focal. The former is usually the consequence of ischemia or a lesion of the end stage kidney. In fact, glomerulosclerosis is an end result of glomerular injury irrespective of cause.

Focal segmental glomerulosclerosis is a clinicopathological entity which is histologically characterized by segmental glomerulosclerosis in some glomeruli, or tuft collapse, segmental hyalinosis, mostly negative or $\operatorname{IgM}$ staining on immunofluorescence and effacement of foot processes on electron microscopy. (Figs. 6,7)

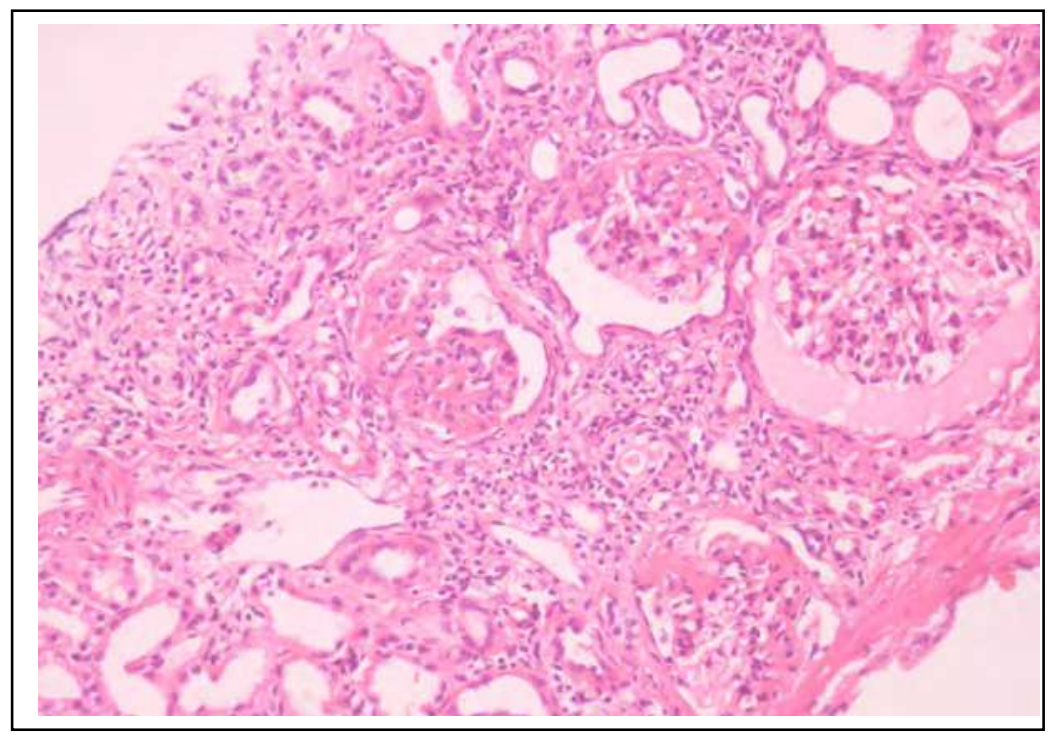

Fig. 6. Focal segmental glomerulosclerosis. The sclerotic lesion involves three glomeruli in a segmental pattern. There is also tubular atrophy with mononuclear inflammatory cell infiltration in the interstitium. (HEx100)

It may be etiologically classified as primary, hereditary disease associated or secondary to infections, drugs/toxins, hyperfiltration, ischemia and as a renal involvement of mitochondrial disease (Thomas, 2009; Gbadegesin, 2011; Baskın, 2011; Emma, 2011; Güçer,2005). (Figs. 8,9) Data from the experimental and human studies has demonstrated that podocyte has a central role in the pathogenesis of FSGS. Identification of products of mutated genes located in the podocyte and its slit diagram has resulted in the recognition of the hereditary forms of FSGS, and NPHS2; (Podocin), CD2AP (CD-associated protein), WT1; (Wilms' tumor1), LAMß2; Laminin B2 ACTN4 (Alfa-actinin4), TRPC6 (Transient receptor potential channel type6), PLCE1(Phospholipase Epsilon1), INF2(Inverted forming 2) and others are classified now genetic causes of FSGS and nephrotic syndrome (Gbadegesin,2011). 


\section{CASE 3.}

A 8 year-old-female presented with the complaints of swelling of eyelids and face lasting for 3 months.

No family history for kidney disease or consanguinity between parents.

Physical examination revealed a high blood pressure of $160 / 90 \mathrm{mmHg}$ and pretibial $3(+)$ pitting edema.

Laboratory findings: Complete blood count was normal, triglyceride $368 \mathrm{mg} / \mathrm{dl}$, BUN 43 $\mathrm{mg} / \mathrm{dl}, \mathrm{Cr}: 0.6 \mathrm{mg} / \mathrm{dl}$, Total protein/Albumin:3.7/1.2 g/dl

Urinalysis: Density 1010, Proteinuria $160 \mathrm{mg} / \mathrm{m} 2 / \mathrm{hr}$, no glucose, sediment: 8-10 white blood cells, 4-5 red blood cells and a few fine granular casts.

Serum C3 ,C4 levels, ANA, Anti-DNA, viral markers were all normal.

Renal USG revealed renal parenchymal disease with increased echogenity.

Renal biopsy diagnosis: Focal segmental glomerulosclerosis (Figs. 6,7)

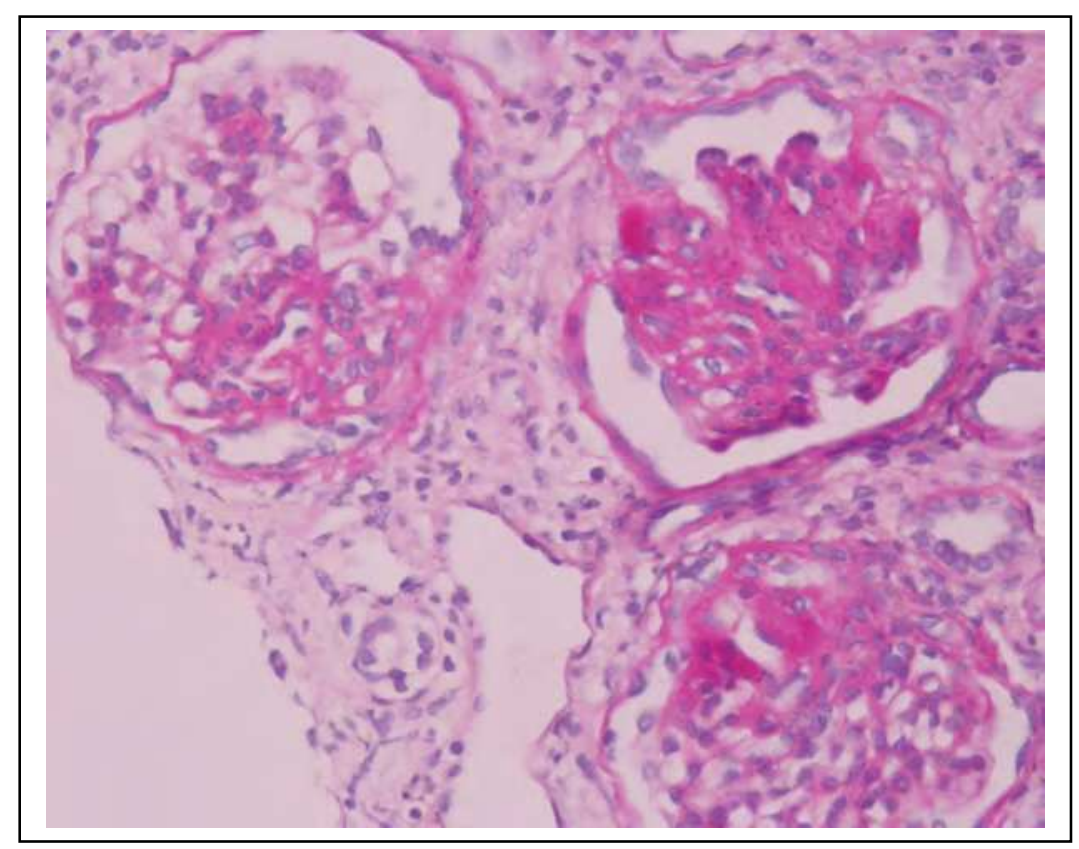

Fig. 7. Focal segmental glomerulosclerosis in 2 glomeruli and global sclerosis and Bowman capsule adhesions in the other. (PAS x200)

\section{CASE 4.}

A a 9 year-old girl admitted to the hospital because of hematuria and proteinuria lasting for two months.

She was initially diagnosed as mitochondrial disease by the findings of ptosis, ophthalmoplegia, failure to thrive, high serum lactate and pyruvate levels, ragged red fibers in muscle biopsy and the common $4.9 \mathrm{~kb}$ deletion in mtDNA. 
She had been followed up for five years without any signs of other organ involvement before she developed hematuria and proteinuria.

On this admission, physical examination revealed failure to thrive, ptosis, hypo- and hyperpigmented areas in both extremities.

Urinalysis showed 2+ proteinuria with normal blood biochemistry.

Urinary protein/creatinine ratio was $0.8, \mathrm{Hb} 12 \mathrm{~g} / \mathrm{dl}$, WBC 7700/mm3 with normal complement components and $\beta 2$ microglobulin levels.

Renal biopsy diagnosis: FSGS associated with mitochondrial disease(Figs.8,9)

Membranous glomerulonephritis(MGN) is mostly the disease of the adults and unusual in children. It can be primary or secondary to infections, drugs, systemic disease, malignant tumors etc. Patients may present with proteinuria, hypertension, hematuria or renal insufficiency. GBMs are the main site of injury and the characteristic pathologic features are thickened GBM along with a predominant IgG deposition of granular type. In early stages, GBM may show normal appearance and mild mesangial hypercellularity (Figs.10,11) (Cybulski,2011;Beck,2010).

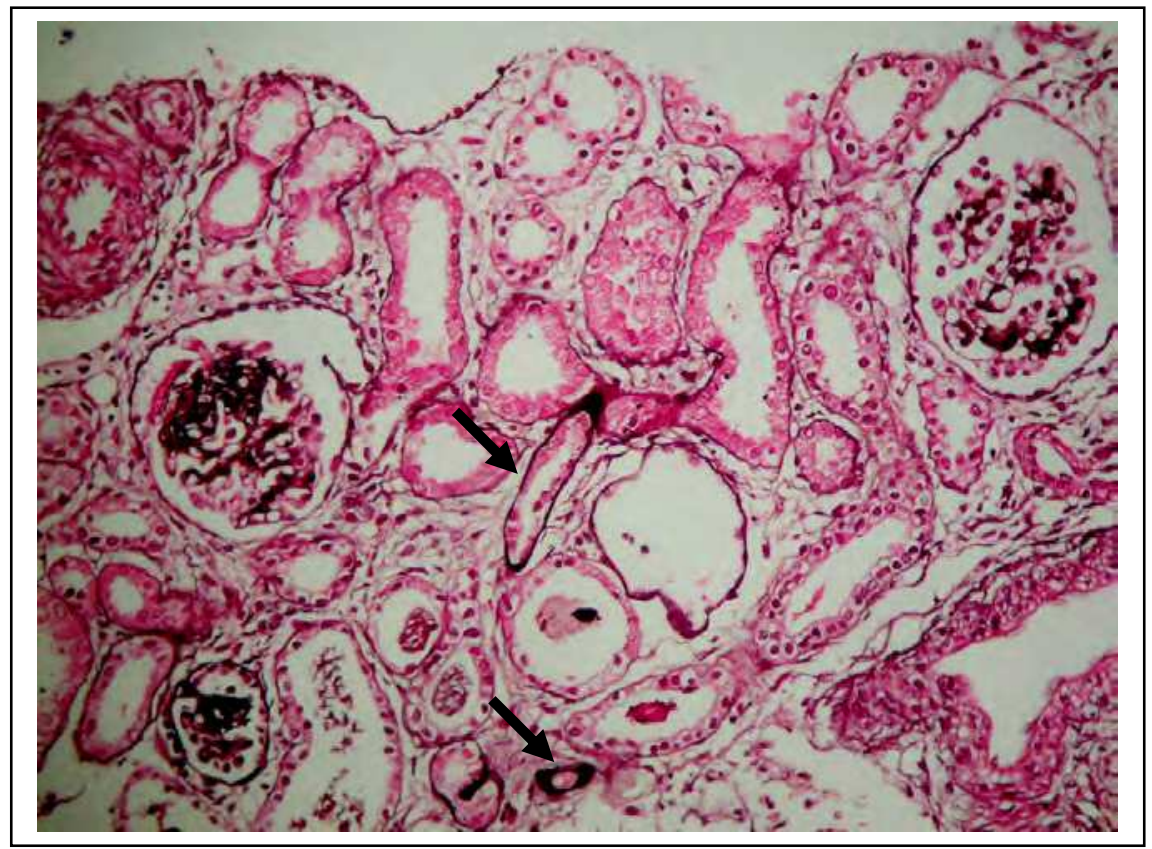

Fig. 8. Renal biopsy of Case 4 shows segmental sclerosis (arrow) in two glomeruli. Note focal atrophy of periglomerular tubules (arrows) and interstitial edema. HE\&JSilverx100. 


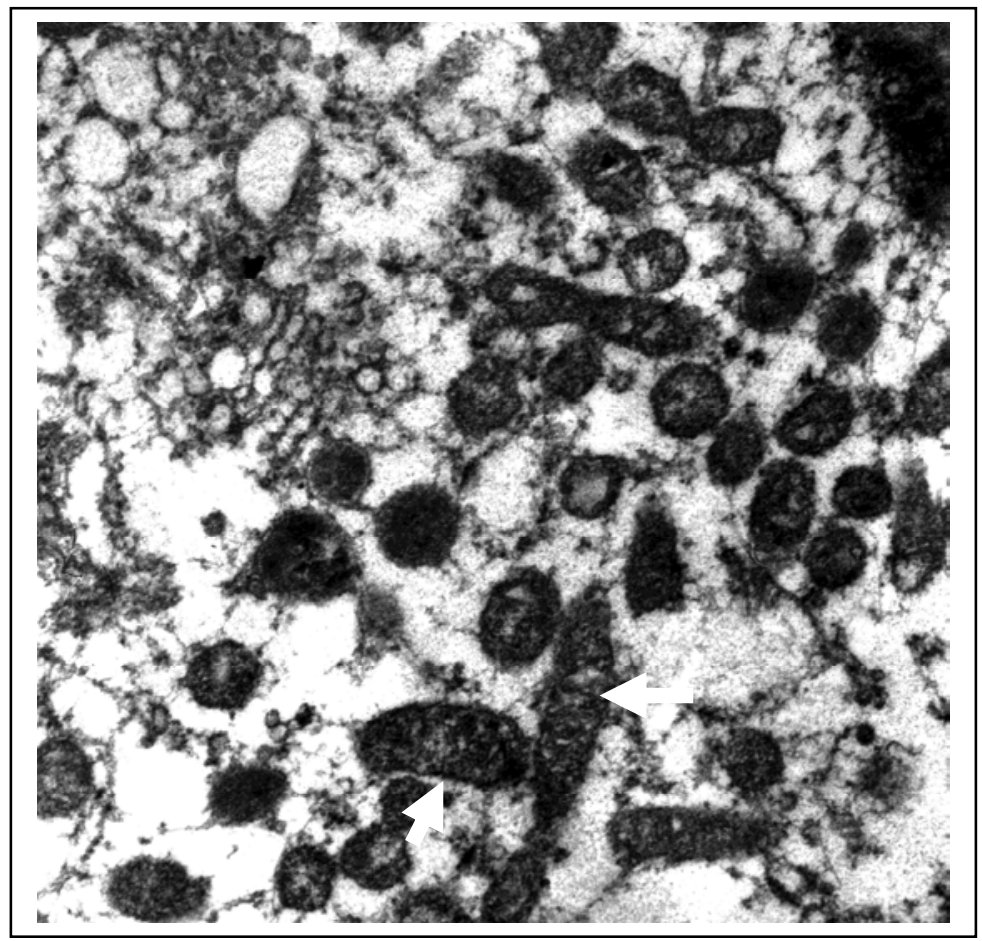

Fig. 9. Ultrastructural details of mitochondria in high magnification: Note increased matrix density and cristae formation. Vesicular structures (arrows) representing the increased cristae formation are evident. Uranyl acetate lead citrate x 20000.

\section{CASE 5.}

A 60 year old man was admitted with edema and hypertension lasting for one month.

No family history for kidney disease.

Physical examination revealed unremarkable findings except a high blood pressure of $170 / 100 \mathrm{mmHg}$ and pretibial $2(+)$ pitting edema.

Laboratory findings: Complete blood count was normal, triglyceride $200 \mathrm{mg} / \mathrm{dl}$, BUN 53 $\mathrm{mg} / \mathrm{dl}$, Cr $1.2 \mathrm{mg} / \mathrm{dl}$, Total protein/Albumin 4/1.6 g/dl

Urinalysis: Density 1020, Proteinuria 3078 mg/ 24hrs, no glucose, sediment:, 10-15 red blood cells.

Serum IgA, IgG, IgM , C3 ,C4 levels, ANA, Anti-DNA, viral markers, CA 125,CA-19-9, CA15-3 Rheumatoid factor, ASO and CRP were all normal.

Renal biopsy diagnosis: Membranous GN (Figs.10,11)

Renal amyloidosis must be included in differential diagnosis of proteinuria or nephrotic syndrome when the light microscopy gives no or minimal histopathological findings. Amyloid deposits in general appear as pink, homogenous and amorphous material in HE sections. Sometimes, the deposits may confine to the mesangium and be barely visible by light microscopy leading a misdiagnosis of minimal change disease. The diagnosis of amyloidosis is made by demonstration of apple-green birefringence under polarized light 


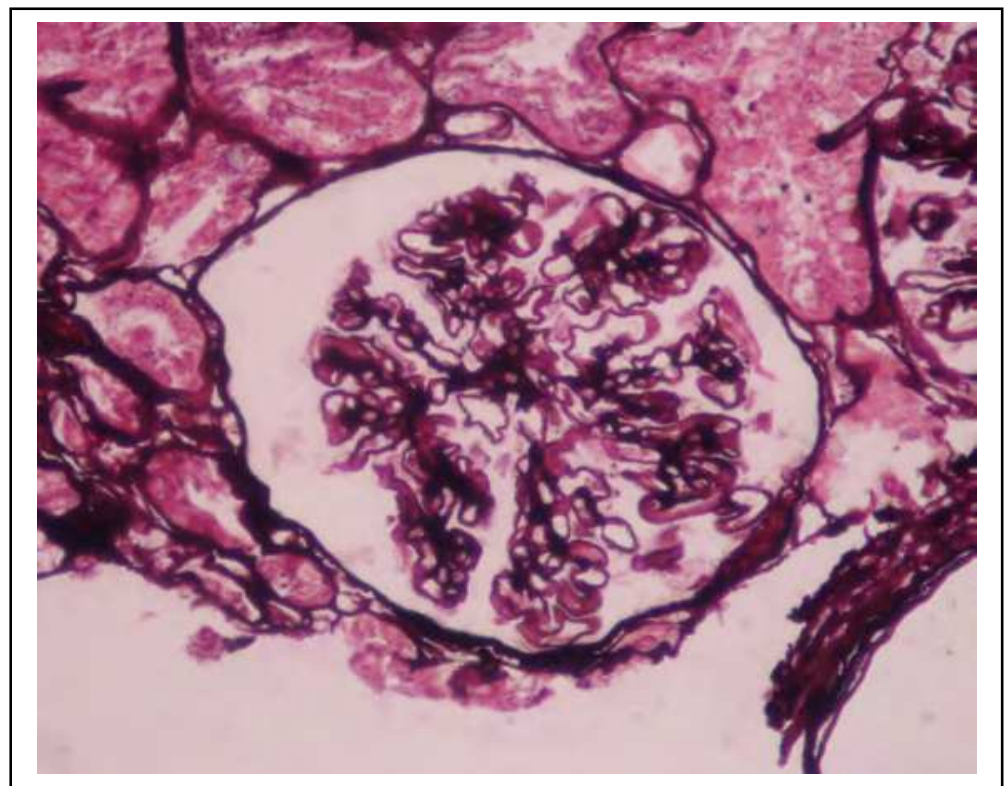

Fig. 10. Membranous GN. Early stage. A slight thickening of glomerular basement membrane. Jones Silver+HE.x400.

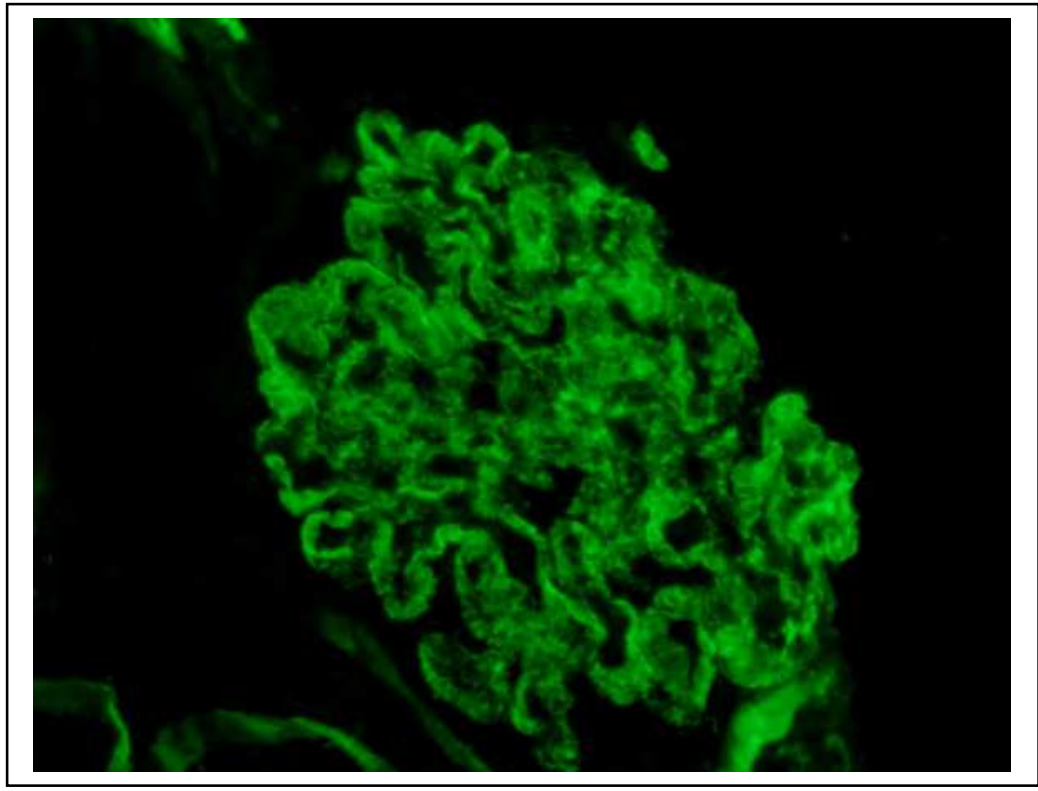

Fig. 11. Membranous GN. Granular type IgG staining of basement membranes in a glomerulus. Immunofluorescence microscopyx 400 . 
in Congo-red stained sections which should be at least 6 microns in thickness.(Şen, 2010; Hopfer, 2011) (Figure 12,13).

\section{CASE 6.}

A 14 year-old-male was admitted to the hospital with the complaints of swelling of legs for 2 months. He had had recurrent fever and abdominal pain for 5 years.

No family history for kidney disease but $1^{\text {st }}$ degree consanguinity between parents.

On physical exam: Blood pressure:100/60 mmHg , pretibial 4(+) pitting edema was noted.

Laboratory findings: Complete blood count and electrolytes were normal ,

BUN $10 \mathrm{mg} / \mathrm{dl}, \mathrm{Cr}: 0.3 \mathrm{~m} \mathrm{~g} / \mathrm{dl}$, Total protein/Albumin: 3.9/1.89 g/dl

Urinalysis: Density 1010, Proteinuria $200 \mathrm{mg} / \mathrm{m} 2 / \mathrm{hr}$, no glucose, sediment: 1-2 white blood cells.

Serum C3 ,C4 levels, ANA, Anti-dsDNA, viral markers were all normal. MEFV mutation:M694V homozygote. Renal USG revealed minimal hyperechogenicity.

Renal biopsy diagnosis: Renal amyloidosis and familial Mediterranean fever(FMF) (Figs.12,13)

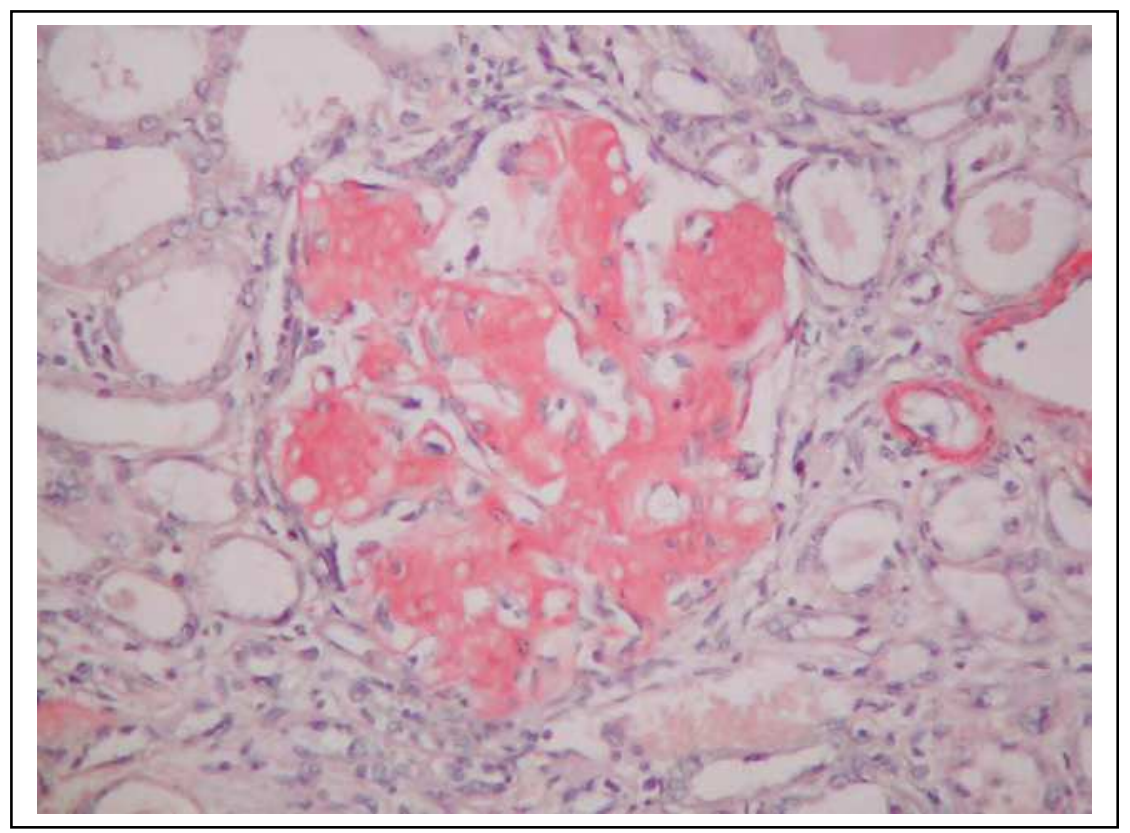

Fig. 12. Renal Amyloidosis. Diffuse nodular amyloid infiltration in a glomerulus. There is also vascular involvement (upper right). Congo red stain $\times 200$. 


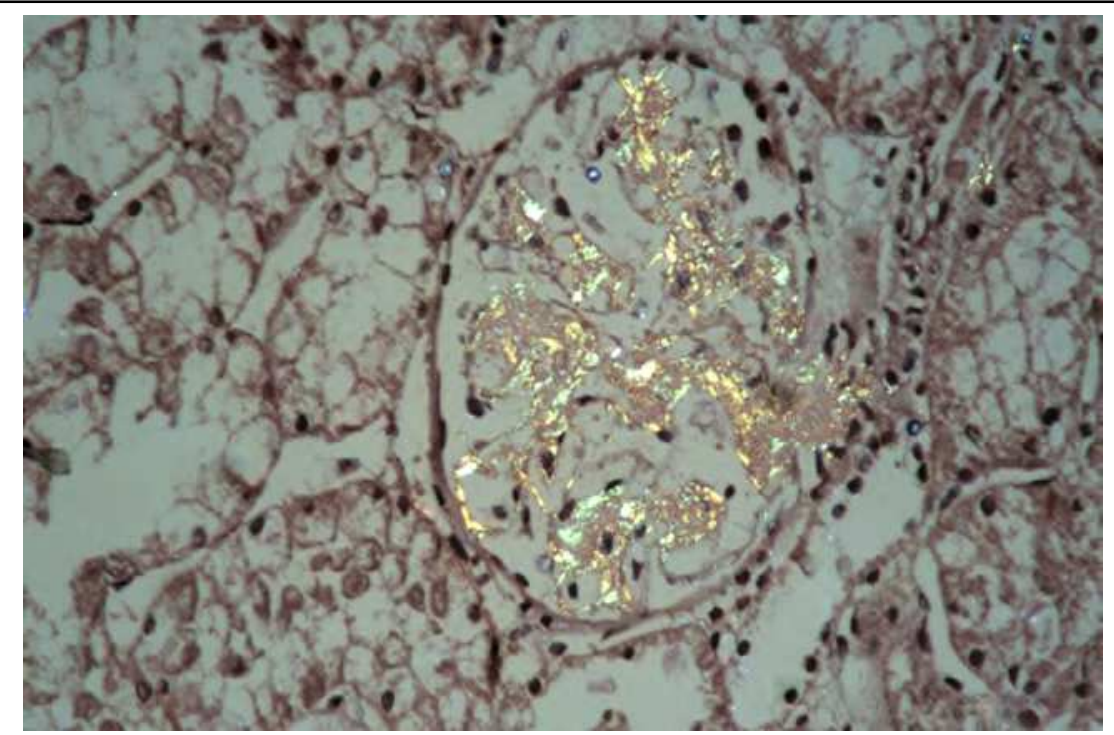

Fig. 13. Apple green birefringence of Congo red stained deposits under polarized light confirming the amyloid. Congo red $x 400$

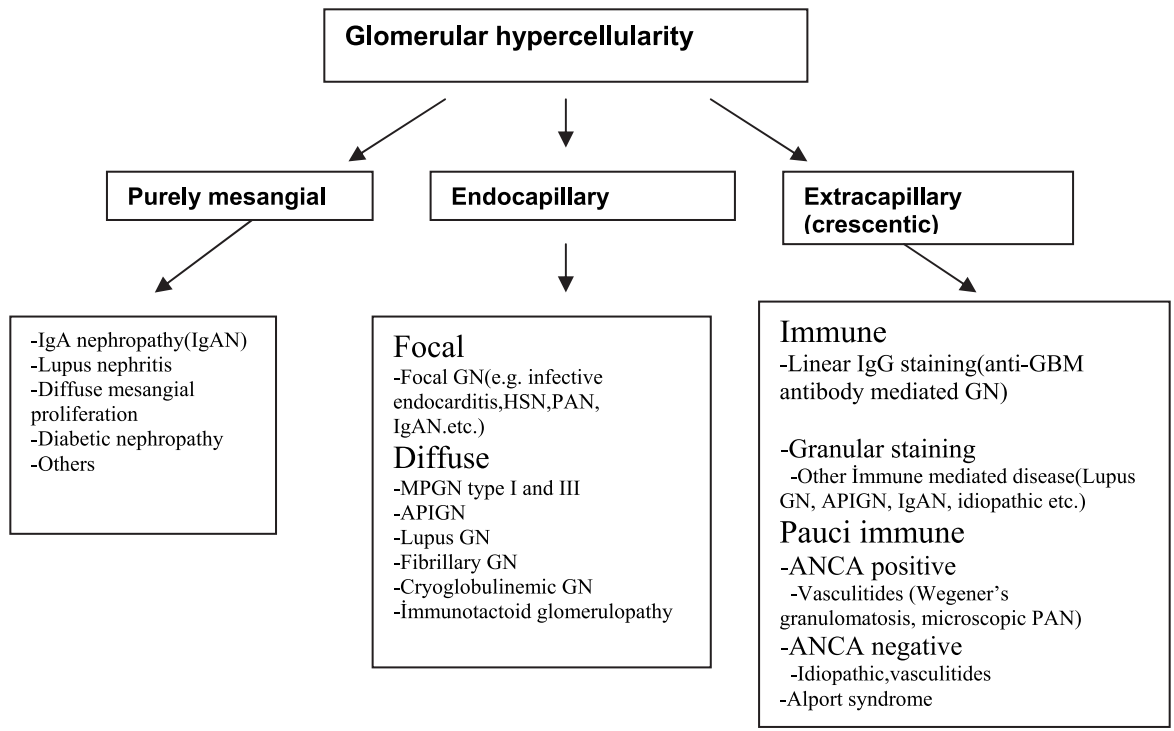

Fig. 14. An algorithm for interpretation of glomerular morphological changes with glomerular hypercellularity.(GN: Glomerulonephritis, MPGN: membranoproliferative GN, APIGN; acute postinfectious GN,ANCA; anti-neutrophil cytoplasmic autoantibodies,PAN; polyarteritis nodosa) 


\subsubsection{Pure mesangial, endocapillary or extracapillary proliferative lesions}

If the glomerular cellularity is increased the algorithm in Fig. 2 is used. At this point one should detect whether the glomerular hypercellularity is purely mesangial, endocapillary (occluding the capillary lumina) or extracapillary. Glomerular lesions may be focal or diffuse based on the percentage of involved glomeruli (i.e focal: the lesion involving less than $50 \%$ of number of glomeruli). Mesangial and Endocapillary proliferation may be segmental or diffuse while extracapillary proliferation may affect the glomerulus partially or globally.(Fogo, 2003; Lajoie \& Silva,1996)

The differential diagnosis of mesangial proliferation depends on mainly immunofluorescence findings. IgA nephropathy is one of glomerular diseases which can present mesangial proliferation and is diagnosed by dominant or co-dominant IgA deposition in glomeruli by immunofluorescence microscopy and electron microscopy. (Cattran, 2009; Bellu, 2011)(Figs 15-17)

\section{CASE 7.}

A 20 year-old-male was admitted to the hospital with the complaints of flank pain and recurrent bouts of hematuria. He had a history of upper respiratory tract infection two days prior to the urinary symptoms.

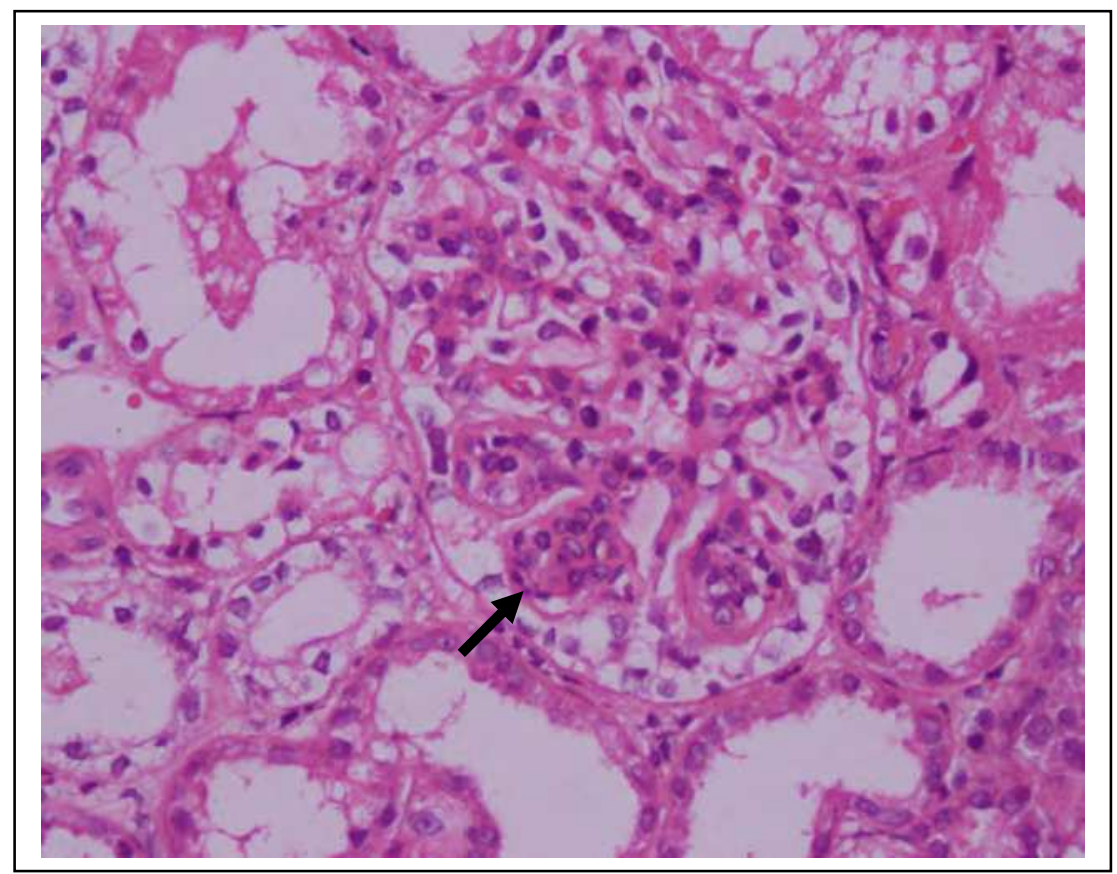

Fig. 15. Microphoto showing segmental endocapillary proliferation(arrow) a case with IgA nephropathy. HEx200. 
No family history for kidney disease or consanguinity between parents.

On physical exam was unremarkable with a blood pressure of 100/60 $\mathrm{mmHg}$.

Laboratory findings: Complete blood count and electrolytes were normal , ESR $30 \mathrm{~mm} / \mathrm{hr}$ BUN 20 mg/dl,Cr:0.8 m g/dl, Total protein/Albumin: 6.9/4 g/dl

Urinalysis: Density 1020, Proteinuria $30 \mathrm{mg} / \mathrm{m} 2 / \mathrm{hr}$, no glucose, sediment: abundant erythrocytes ,15-20 white blood cells and granular casts.

Serum C3,C4 levels, ANA, Anti-DNA, viral markers were all normal.

Renal USG revealed minimal increase in echogenicity and no evidence of urinary stone.

Renal biopsy diagnosis: IgA nephropathy (Figs. 15-17)

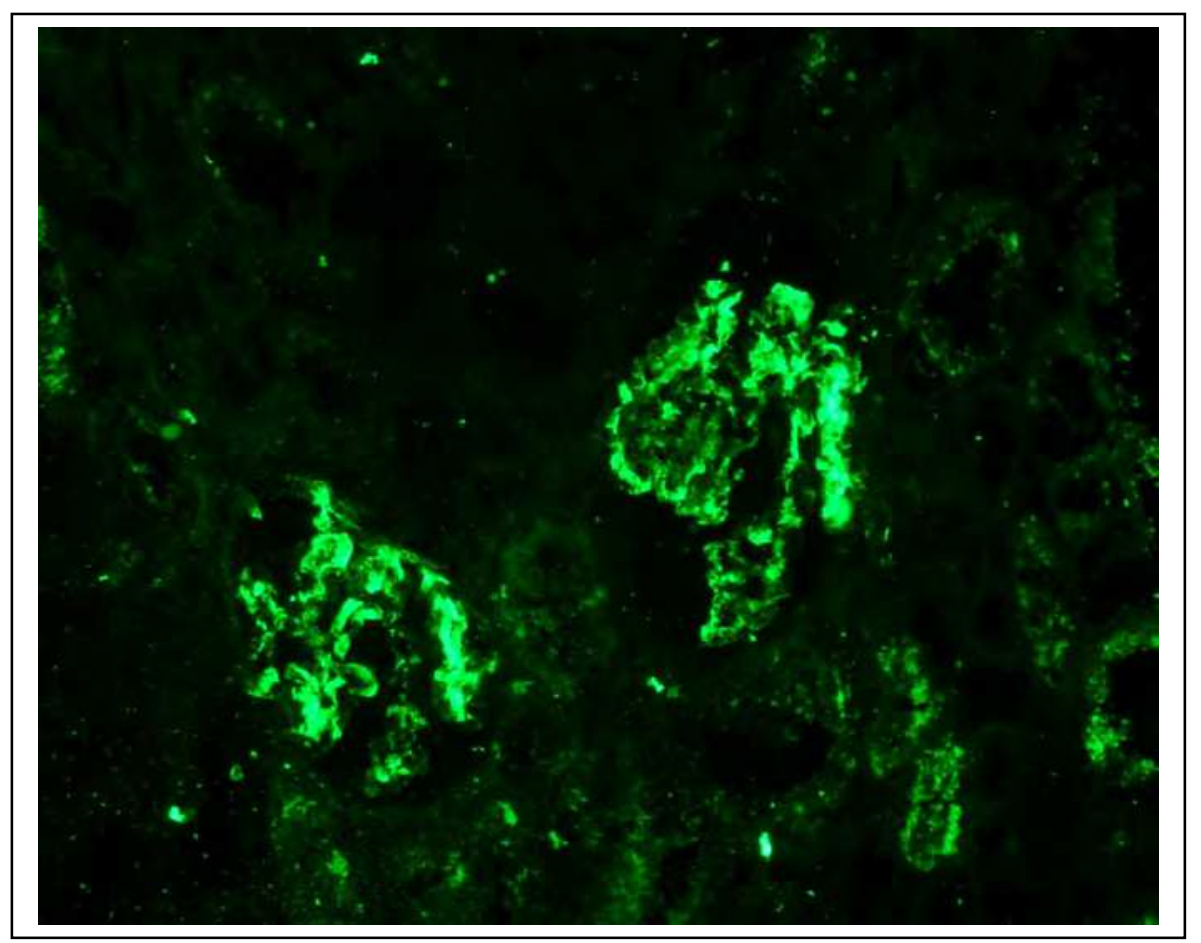

Fig. 16. IgA nephropathy. Mesangial distrubution of IgA deposits in two glomeruli. Immunofluorescence microscopy x200.

Mesangial and endocapillary proliferation can be seen together in membranoproliferative glomerulonephritis(MPGN) type 1, dense deposit disease(MPGN type 2), lupus nephritis, cryoglobulinemic GN, postinfectious GN, fibrillary GN or immunotactoid glomerulopathy. Then, immunofluorescence and electron microscopy are of vital importance for differential diagnosis. On the other hand, crescent formation not uncommonly associates to endocapillary proliferative ,necrotic or vasculitic lesions. The lesion is the consequence of capillary wall injury and proliferation of parietal epithelial cells. It can be categorized as 


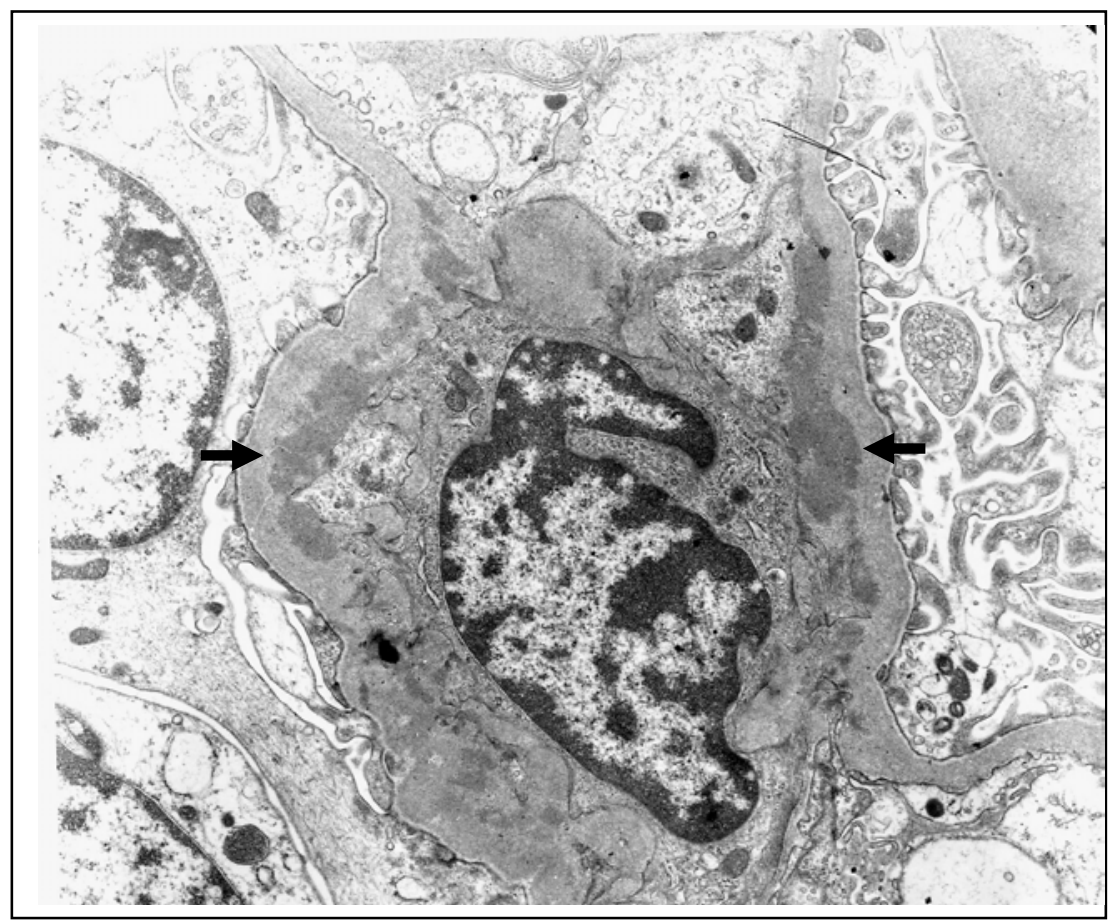

Fig. 17. IgA nephropathy. Electron microscopy shows immune deposits in the mesangial cell(arrows) uranyl acetate lead citrate x 8000 .

immune mediated(lupus nephritis, acute postinfectious, anti GBM nephritis, IgA nephropathy etc.) or pauci-immune (Wegener's granulomatosis, microscopic PAN etc.)(Alchi,2010;Colucci,2011;Nasr,2008).(Figures 19-22)

\section{CASE 8.}

A 17 year-old-male presented with the complaints of hematuria and swelling of whole body. No family history for kidney disease or consanguinity between parents.

On physical exam was unremarkable except a blood pressure of 160/100 $\mathrm{mmHg}$ and pretibial 1+ edema.

Laboratory findings: Complete blood count and electrolytes were normal , CA $7.8 \mathrm{mg} / \mathrm{dl}, \mathrm{P}$ $5.2 \mathrm{mg} / \mathrm{dl}$, BUN $40 \mathrm{mg} / \mathrm{dl}, \mathrm{Cr}: 1.2 \mathrm{mg} / \mathrm{dl}$, Total protein/Albumin: 4.14/2.7 g/dl

Urinalysis: Density 1027, Proteinuria $500 \mathrm{mg} / 24 \mathrm{hrs}$, no glucose, sediment: abundant erythrocytes and white blood cells with fine granular casts.

Serum C3 40 mg/dl, ,C4 12.1mg/dl, ANA, Anti-DNA, viral markers were all normal. Renal USG revealed minimal increase in echogenicity and no evidence of urinary stone.

Renal biopsy diagnosis: Membranoproliferative glomerulonephritis(MPGN) type 1 (Figs.15-17) 


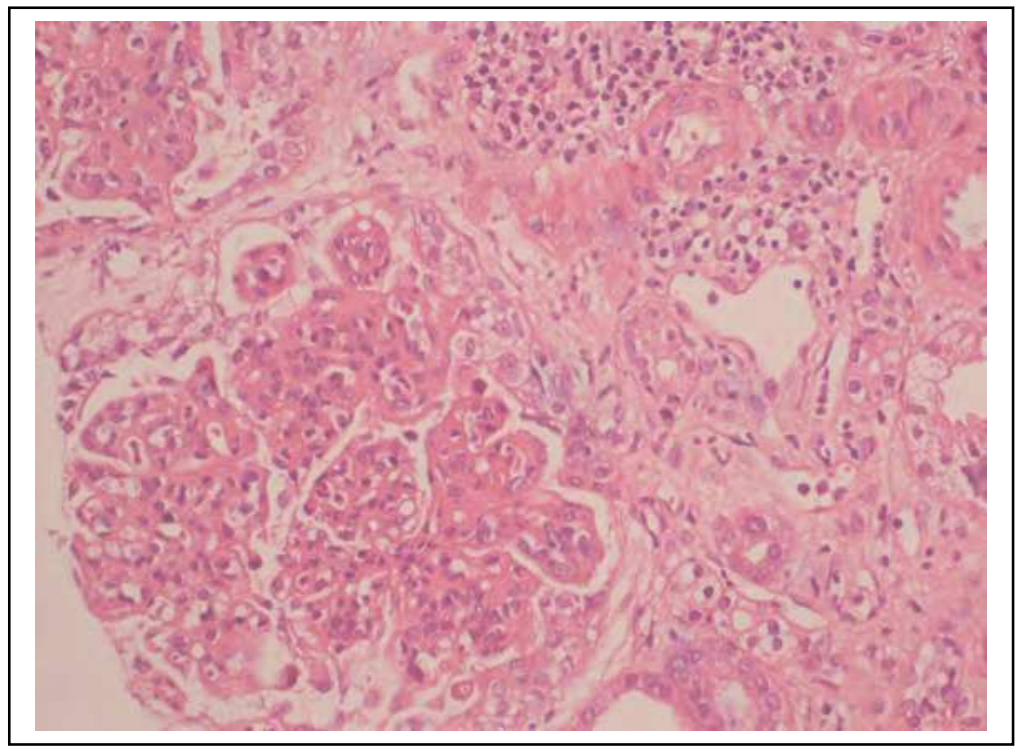

Fig. 18. Membranoproliferative glomerulonephritis. Note endocapillary proliferation, lobulation and thickening of glomerular capillary walls. A mononuclear inflammatory cell infiltration with tubular atrophy in the interstitium is also seen. HEx200.

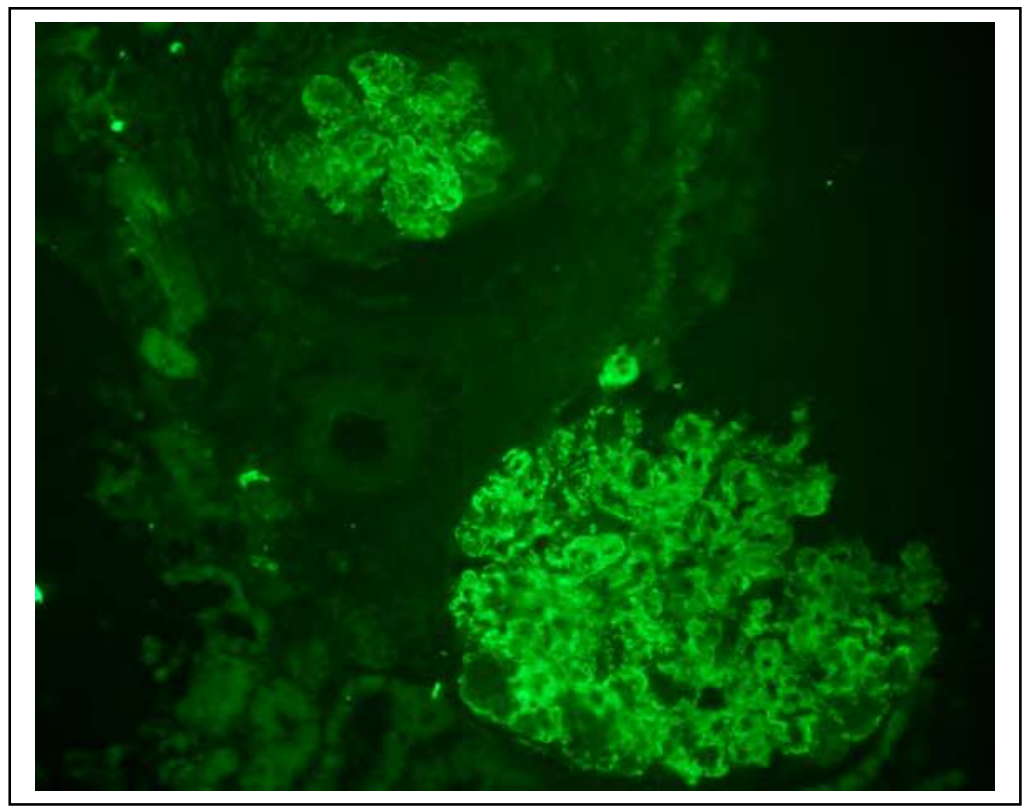

Fig. 20. Membranoproliferative type $1 \mathrm{GN}$. Granular frame-like staining of C3 the basement membrane and mesangium in 2 glomeruli. Immunofluorescence microscopyx 200. 


\section{CASE 9.}

A 15 year-old-male presented with the complaints of hematuria, oliguria and swelling of his face and eyelids. He suffered a throat infection 10 days prior to admission. No family history for kidney disease or consanguinity between parents.

On physical exam was unremarkable except a blood pressure of 160/100 $\mathrm{mmHg}$ and pretibial 1+ edema.

Laboratory findings: Complete blood count and electrolytes were normal , BUN 98 $\mathrm{mg} / \mathrm{dl}$,Cr:9.34 mg/dl, Total protein/Albumin: 6.14/3.2 g/dl

Urinalysis: Density 1018, Proteinuria $1200 \mathrm{mg} / 24 \mathrm{hrs}$, no glucose, sediment: abundant erythrocytes and white blood cells and fine leukocytic and granular casts.

Serum C3 15 mg/dl, ,C4 6.1mg/dl, ANA, Anti-DNA, viral markers were all normal.

Renal USG revealed minimal increase in parenchymal echogenicity . Urine culture was negative.

Renal biopsy diagnosis: Acute postinfectious glomerulonephritis(APIGN) (Figs.21-22)

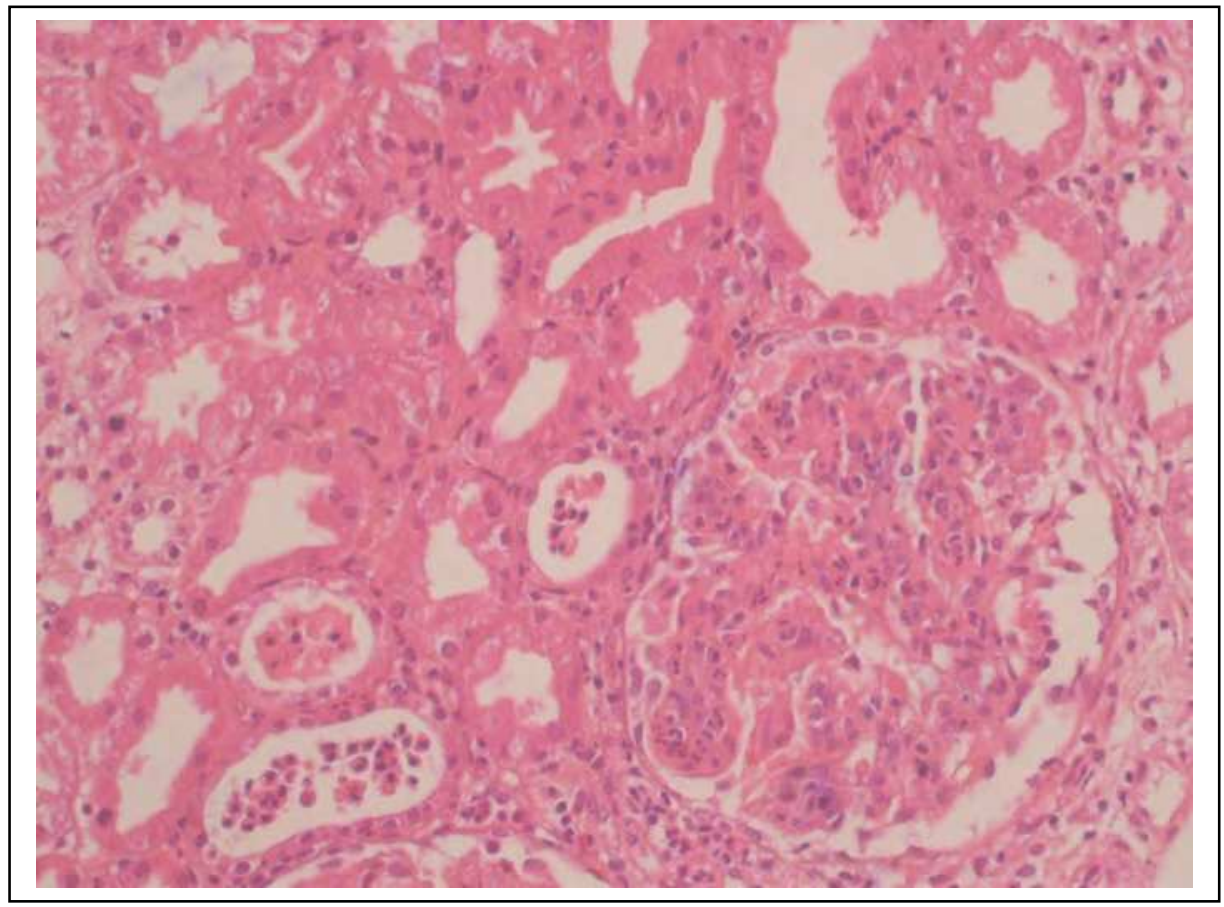

Fig. 21. Acute postinfectious glomerulonephritis. Light micrograph shows endocapillary proliferation with numerous neutrophils. There are also several neutrophils in tubular lumina.HEx200. 


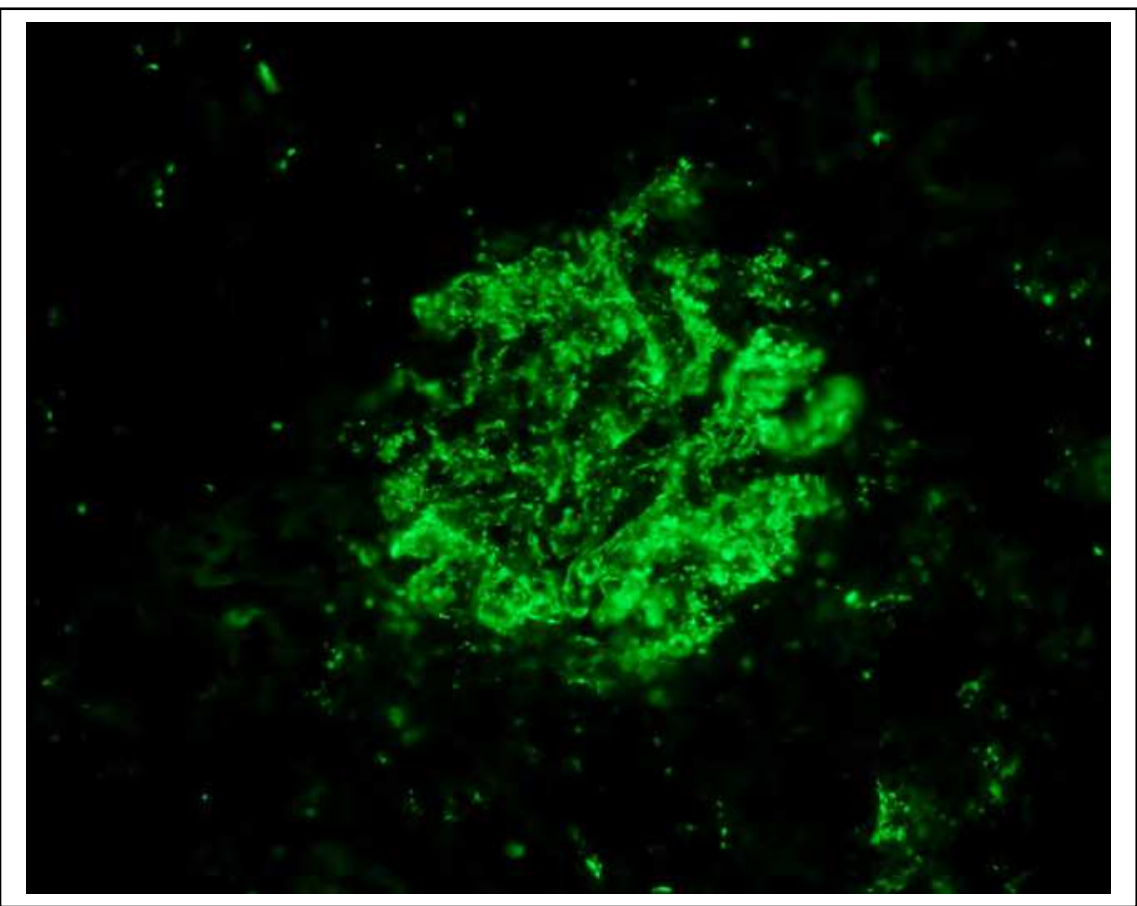

Fig. 22. Acute postinfectious GN. Immunofluorescence microphoto shows a starry sky pattern. There is a diffuse fine or coarse granular deposits of C3 in the GBM and mesangium. Immunofluorescence microscopyx 200 .

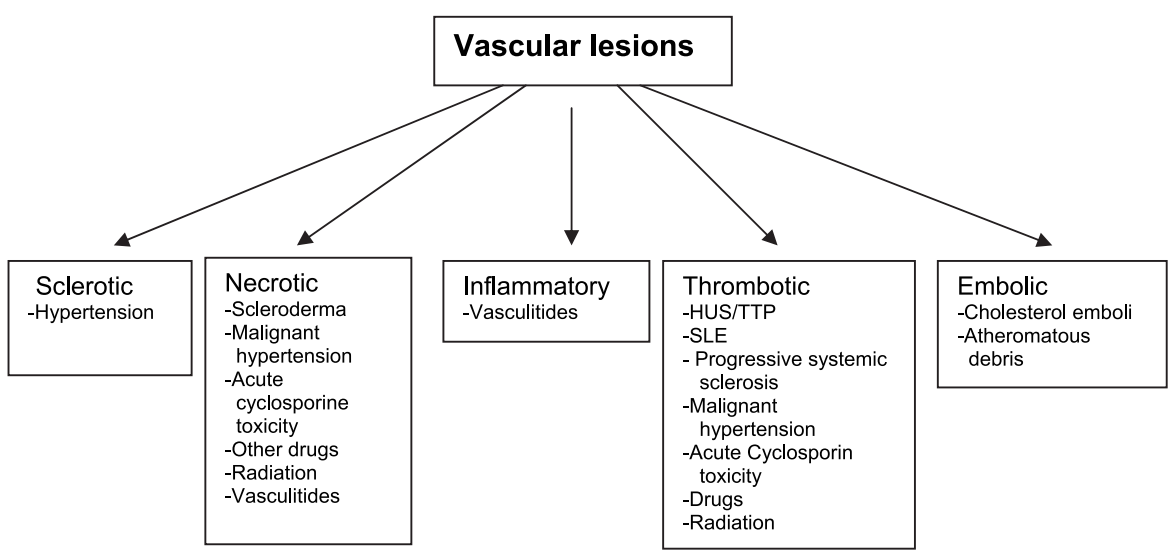

Fig. 23. An algorithm for interpretation of vascular lesions.(HUS: Hemolytic uremic syndrome, TTP: Thrombotic Thrombocytopenic purpura, SLE: Systemic lupus erythematosus) 


\subsubsection{Vascular lesions}

Vascular lesions can be divided into five broad groups. Intimal fibrosis/medial fibrosis is associated with hypertension whereas necrosis may be a sign of progressive systemic sclerosis, vasculitis, drug hypersensitivity or radiation. Thrombotic lesions can be due to thrombotic microangiopathy/ hemolytic uremic syndrome, lupus nephritis + antiphospholipid syndrome, malignant hypertension and progressive systemic sclerosis. (Silvarin, 2011; Lindsay, 2011; Benz,2010) (Figures 24,25)

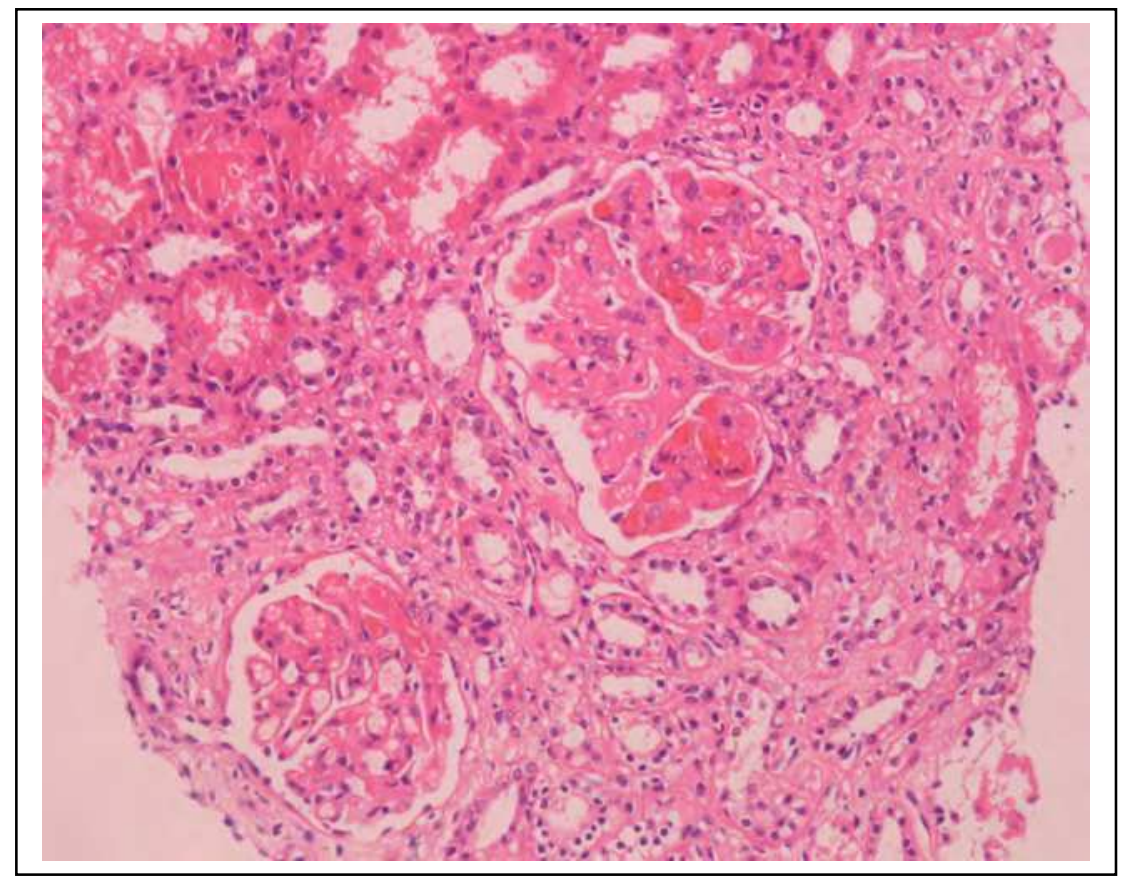

Fig. 24. Lupus nephritis+ thrombotic microangiopathy. Note 'wire-loops(down left) and fibrin thrombi obliterating glomerular capillary lumina. HEx100

\subsubsection{Tubulointerstitial lesions}

Tubulointerstitial lesions can be divided into five main categories including interstitial cellular infiltrates, necrosis, edema, tubular atrophy/fibrosis and tubular casts/deposits. If there is a significant infiltration in the tubulointerstitial area it is crucial to determine whether it is benign or malignant.(Figure 26). If benign, then the predominant cell type in the infiltration should be assessed or if there is no significant inflammation, necrosis, edema, tubular atrophy / fibrosis, tubular casts and deposits are investigated according to the main tubular abnormalities.(Figures 27,28) (Kowalewska,2011; Simms,2011; Wolf,2011; Midgley,2011;Chandra,2010) 


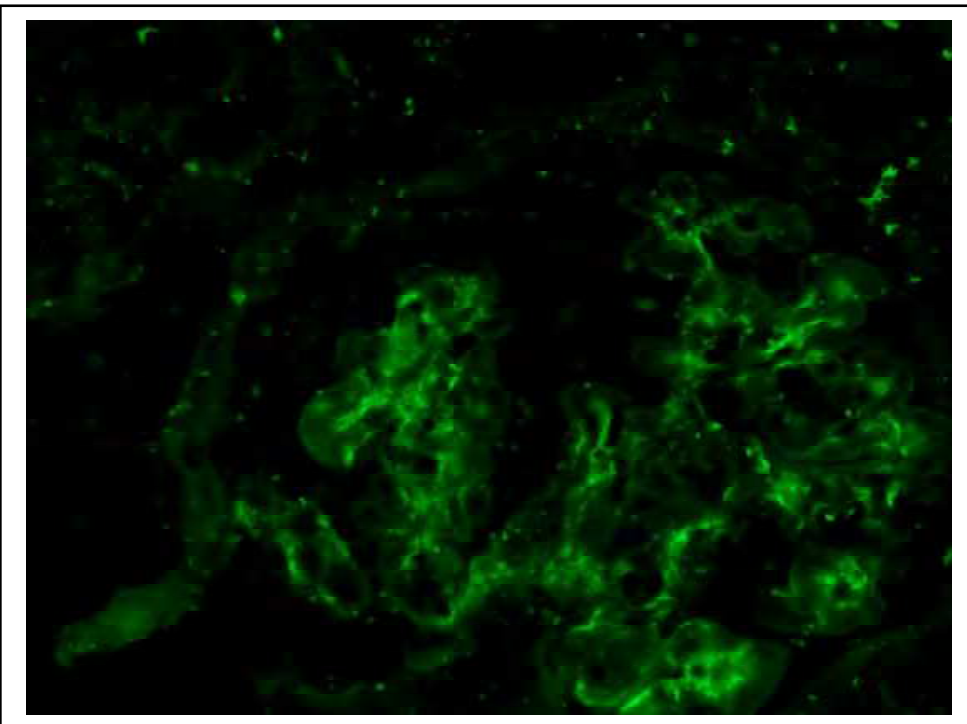

Fig. 25. Lupus nephritis+ thrombotic microangiopathy. IgG staining of glomerular basement membrane and mesangium. Immunofluorescence microscopyx 400.

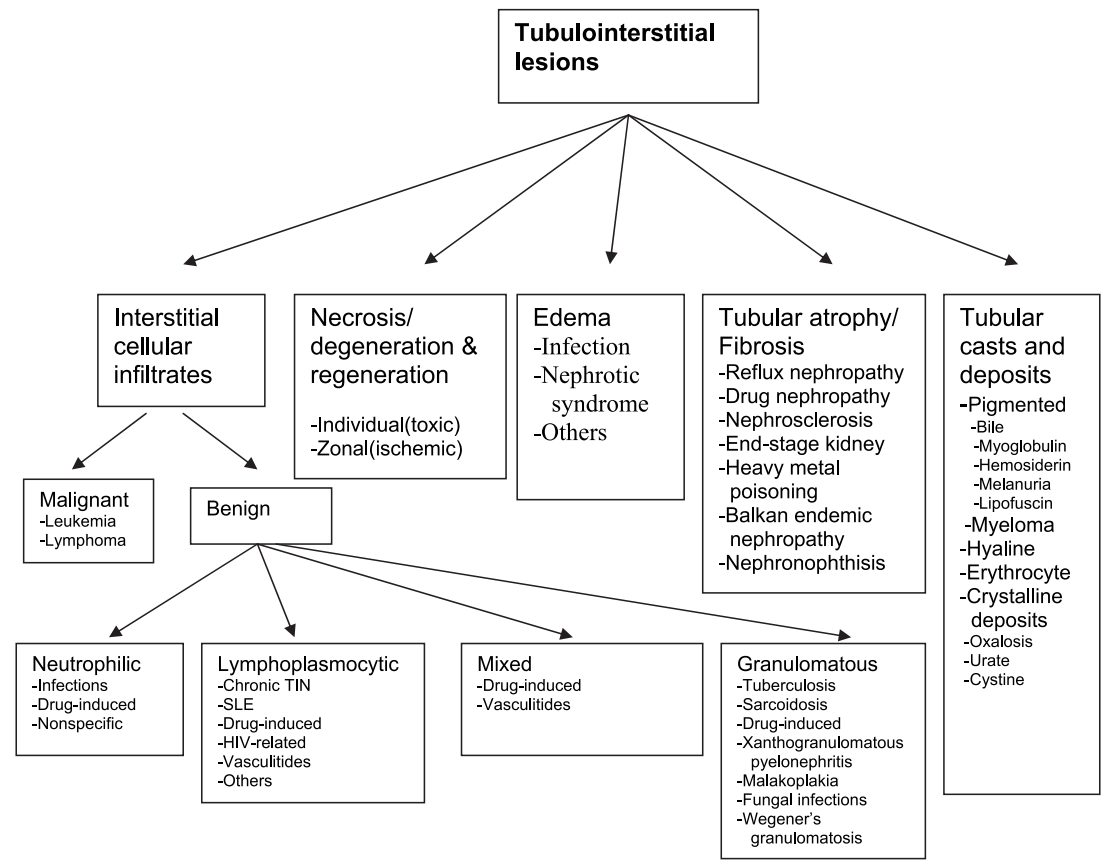

Fig. 26. An algorithm for interpretation of tubulointerstitial lesions. (TIN: Tubulointerstitial nephropathy, SLE:Systemic lupus erythematosus,HIV; Human immunodeficiency virus) 


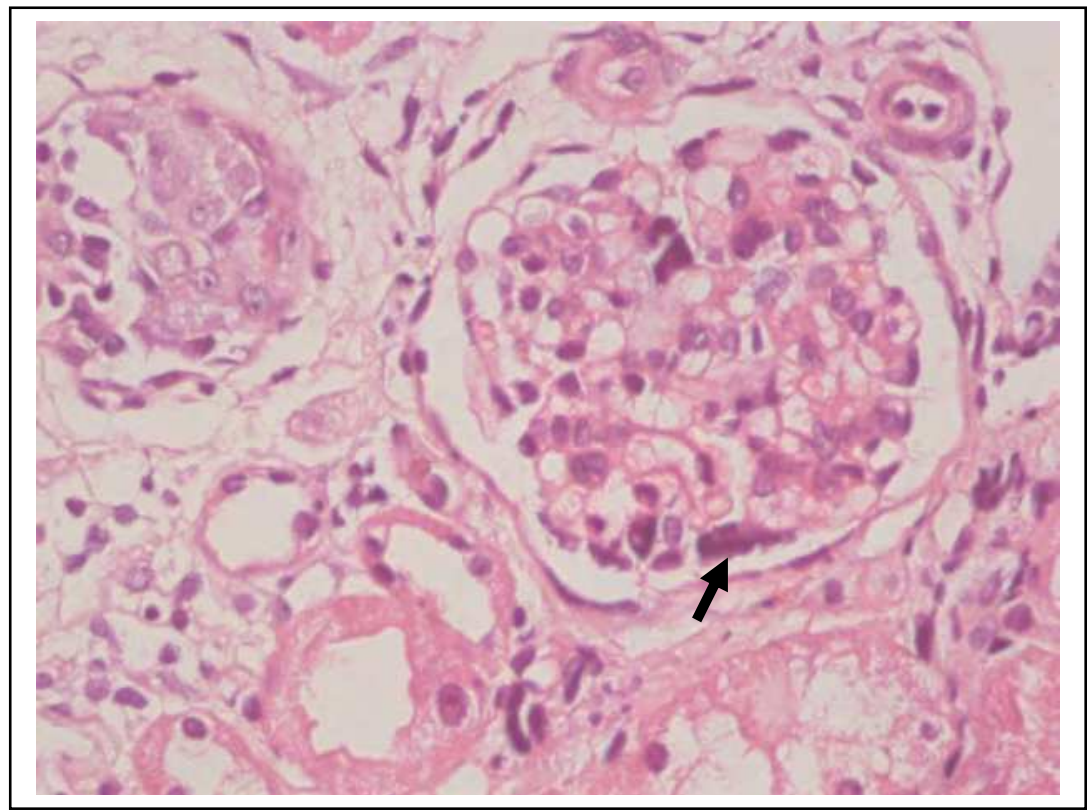

Fig. 27. Cystinosis. Multinuclear podocytes may be an early sign of cystinosis(arrow). HEx200.

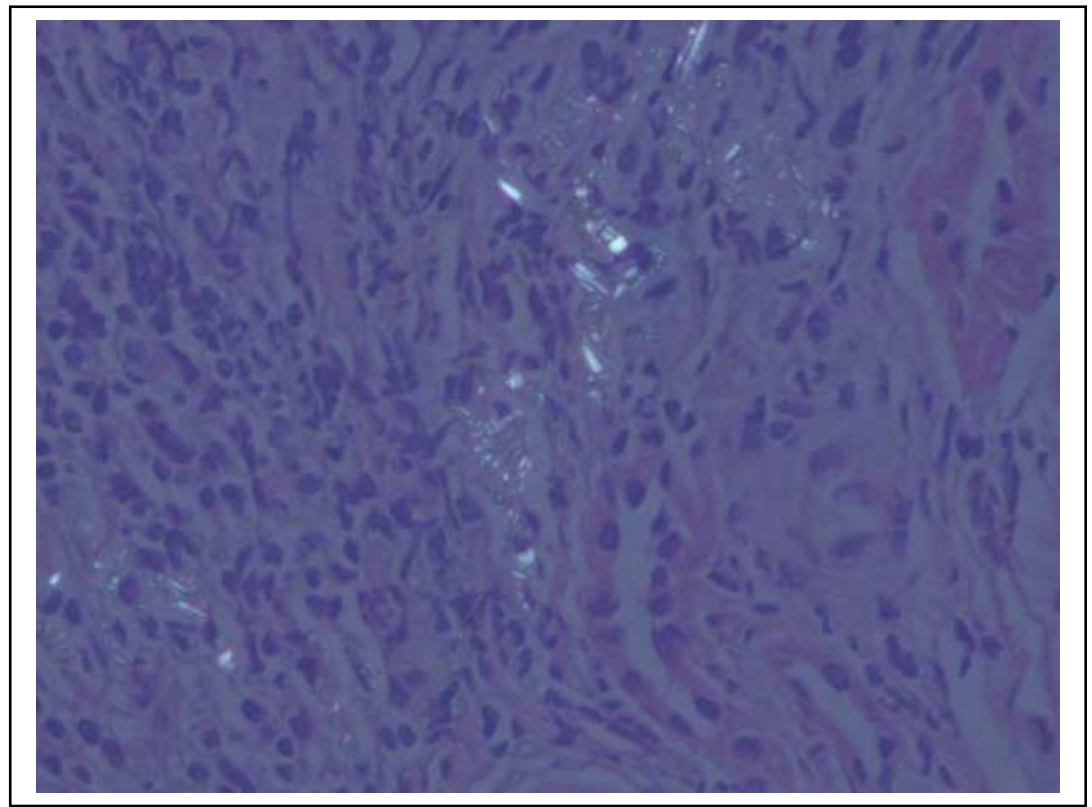

Fig. 28. Cystinosis. Cystine crystals in the interstitium under polarized light.HEx400. 


\section{CASE 10.}

A 3 year-old-male presented with the complaints of polyuria, polydipsia and oliguria lasting eight months. No family history for kidney disease but $2^{\text {nd }}$ degree consanguinity between parents.

Physical examination revealed a malnourished infant with failure to thrive.

Laboratory findings: Complete blood count and electrolytes were normal , Ca $9.8 \mathrm{mg} / \mathrm{dl}, \mathrm{P}$ $3.97 \mathrm{mg} / \mathrm{dl}$, BUN $30 \mathrm{mg} / \mathrm{dl}, \mathrm{Cr}: 0.7 \mathrm{mg} / \mathrm{dl}$, Total protein/Albumin: 7.4/4.3 g/dl

Urinalysis: Density 1006, Proteinuria $200 \mathrm{mg} / 24 \mathrm{hrs}$, glucose $(+)$, sediment: 7-8 erythrocytes and 5-6 white blood cells. Serum C3 $90 \mathrm{mg} / \mathrm{dl}$, ,C20.1mg/dl, ANA, Anti-DNA, viral markers were all normal. Ultrasonography revealed increase in renal parenchymal echogenicity.

Renal biopsy diagnosis: Cystinosis (Figs.27-28)

\subsection{Transplant kidney lesions}

Renal allograft biopsy is still the gold standard for diagnosis of transplant rejection. A number of both immune complex( such as MPGN, IgA nephropathy etc.) or non-immune disease(FSGS,diabetic nephropathy etc.) can recur in transplanted kidneys. (Sun,2011; John,2010)(Figure 29)

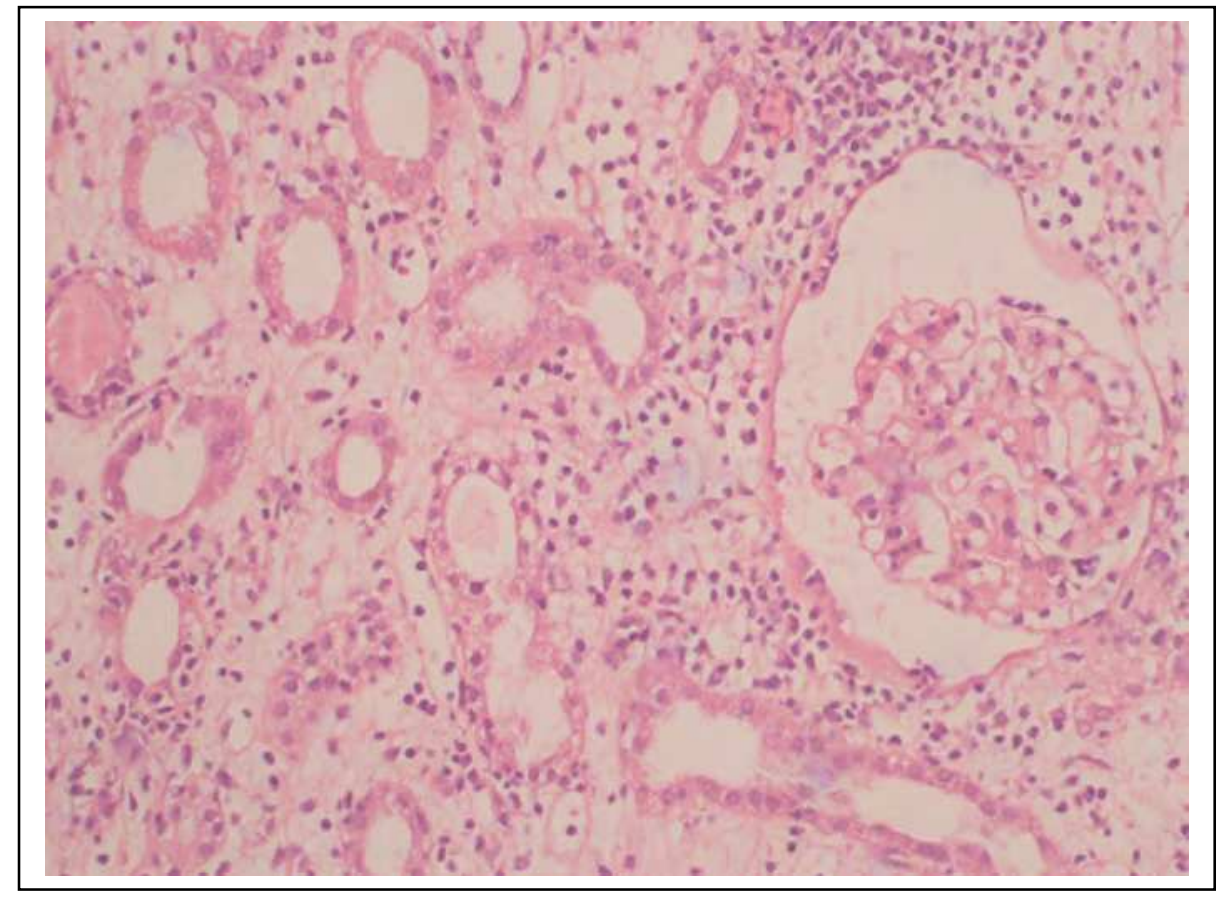

Fig. 29. Acute cellular rejection, Banff type 2. Light microscopic photo showing mildmoderate tubulitis along with tubulointerstitial inflammation. Note that the morphology of glomerulus is unremarkable.HEx100. 


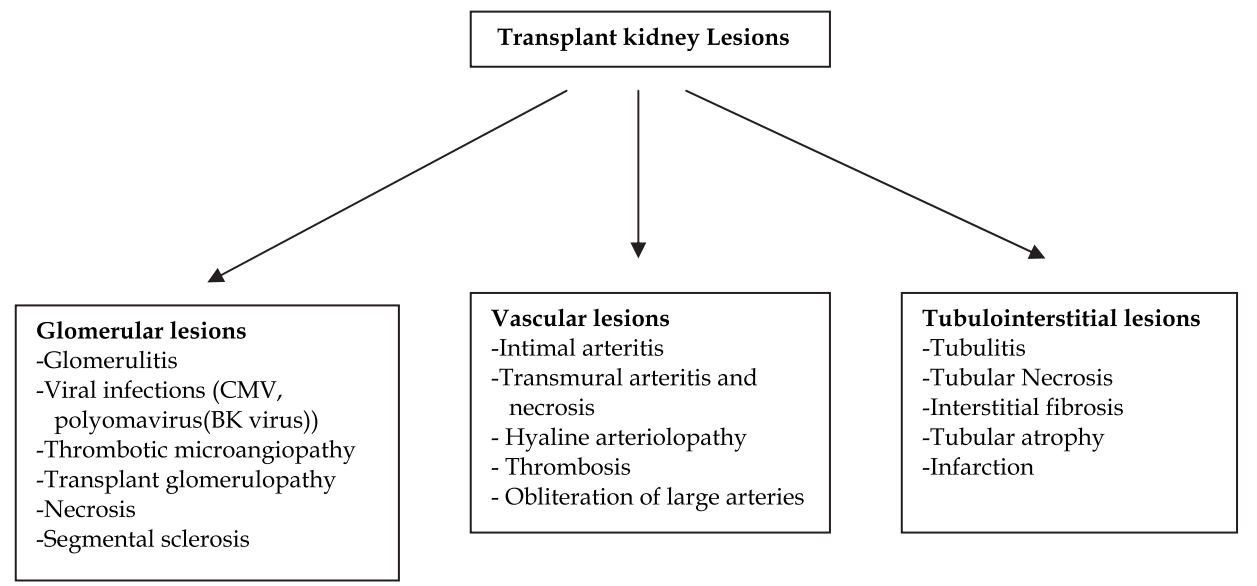

Fig. 30. Types of lesions commonly seen in transplanted kidneys. (CMV: Cytomegalovirus)

\section{Conclusion}

It should be remembered that these algorithms are designed for the diseases presenting with their classical patterns. Therefore, very rarely seen diseases or those without fully developed features are not included in the aforementioned algorithms. Since a number of disease may belong to more than one category because of diversity of the clinical and morphologic findings they may not clearly fall into any category. In addition, the best way to reach a correct diagnosis in a renal biopsy needs making a good correlation of morphological findings with appropriate clinical data.

In the future, a considerable amount of molecular genetic data are anticipated to be added. The aim is to use these data validated in large populations not only to create new algorithms providing the best approach to classify renal diseases but also to obtain complementary knowledge for appropriate prediction concerning diagnosis, therapy and prognosis of renal diseases.

\section{References}

Walker PD(2009). The renal biopsy. Archieves of Pathology \& Laboratory Medicine, Vol. 133, No.2 ( February 2009), pp181-188, ISSN 0003-9985

Walker PD, Cavallo T\& Bonsib SM, (2004).The Ad Hoc Committee on renal biopsy guidelines of the Renal Pathology Society. Practice Guidelines for the renal biopsy. Modern Pathology, Vol.17, No.12 ( December 2004), pp.1555-1563, ISSN 0893-3952

Kretzler M, Cohen CD, Doran P, Henger A, Madden S, Gröne EF, Nelson PJ, Schlöndorff D\& Gröne HJ.(2002). Repuncturing the renal biopsy: strategies for molecular diagnosis in nephrology. Journal of the American Society of Nephrology, Vol.13 No.7, (July 2002), pp 1961-1972, ISSN 1555-9041

Fogo AB.(2003). Approach to Renal Biopsy. American Journal of Kidney Diseases, Vol.42, No.4, (October 2003), pp 826-836, ISSN 0272-6386 
Furness PN.(2000). Acp. Best practice no 160. Renal biopsy specimens. Journal of Clinical Pathology, Vol.53, No.6, (June 2000), pp. 433-438, ISSN 0021-9746

Lajoie J \& Silva FG. (1996). Appoach to the interpretation of Renal Biopsy. Renal Biopsy Interpretation Silva FG, D'agati VD, Nadasdy T(eds). pp 31-70.:Churchill Livingstone Inc.,0-443-07784-03, New York.

Mubarak M,. Kazi JI, Lanewala A, Hashmi S \& Fazal Akhter .( 2011).Pathology of idiopathic nephrotic syndrome in children: are the adolescents different from young children? Nephrol. Dial. Transplant.;doi: 10.1093/ndt/gfr221

Zhang S, Audard V, Fan Q, Pawlak A, Lang P\&Sahali D.(2011). Immunopathogenesis of idiopathic nephrotic syndrome. Contributions to Nephrology, Vol.169 No.1 (January 2011), pp. 94-106, ISSN 0302-5144

Kashtan CE.(2009). Familial hematuria. Pediatric Nephrology, Vol.24 No.10 (October 2009), pp 1951-1958, ISSN 0931-041X.

Savige J, Rana K, Tonna S, Buzza M, Dagher H\&Wang YY.(2003). Thin basement membrane nephropathy. Kidney International, Vol.64, No.4 (October 2003), pp 1169-1178, ISSN 0085-2538

Haas M.(2009). Alport syndrome and thin glomerular basement membrane nephropathy: a practical approach to diagnosis. Archives of Pathology \& Laboratory Medicine, Vol.133, No.2 (February 2009), pp 224-232, ISSN 0003-9985

Thomas DB.(2009). Focal segmental glomerulosclerosis: a morphologic diagnosis in evolution. Archives of Pathology \& Laboratory Medicine, Vol.133, No.2 (February 2009), pp 217-223, ISSN 0003-9985

Gbadegesin R, Lavin P, Foreman J\& Winn M.(2011). Pathogenesis and therapy of focal segmental glomerulosclerosis: an update. Pediatric Nephrology, Vol.26 No.7 (July 2011), pp 1001-1015, ISSN 0931-041X

Baskin E, Selda Bayrakci U, Alehan F, Ozdemir H, Oner A, Horvath R, Vega-Warner V, Hildebrandt F\& Ozaltin F. Respiratory-chain deficiency presenting as diffuse mesangial sclerosis with NPHS3 mutation. Pediatric Nephrology, Vol.26 No.7 (July 2011), pp 1157-1161, ISSN 0931-041X

Emma F, Bertini E, Salviati Montini G.(2011) Renal involvement in mitochondrial cytopathies. Pediatr Nephrol. 10.1007/s00467-011-1926-6

Güçer S, Talim B, Aşan E, Korkusuz P, Ozen S, Unal S, Kalkanoğlu SH, Kale G\&Cağlar M.(2005). Focal segmental glomerulosclerosis associated with mitochondrial cytopathy: report of two cases with special emphasis on podocytes. Pediatric and Developmental Pathology, Vol.8, No.6 (November-December 2005), pp 710-717 ISSN 1093-5266

Cybulsky AV. (2011).Membranous Nephropathy. Review.Contrib Nephrol.Vol.169, No.1 (January 2011), pp. ;107-25 , ISSN 0302-5144

Beck LH Jr.(2010). Membranous nephropathy and malignancy. Seminars in Nephrology, Vol.30, No.6 (November 2010), pp. 635-644, ISSN 0270-9295

Sen S, Sarsik B.(2010). A proposed histopathologic classification, scoring, and grading system for renal amyloidosis: standardization of renal amyloid biopsy report. Archives of Pathology \& Laboratory Medicine, Vol.134, No.4 (April 2010), pp 532544, ISSN 0003-9985

Hopfer H, Wiech T\& Mihatsch J(2011). Renal amyloidosis revisited: amyloid distribution, dynamics and biochemical type. Nephrol Dial Transplant .doi: 10.1093/ndt/gfq831 
Cattran DC, Coppo R, Cook HT, Feehally J, Roberts IS, Troyanov S, Alpers CE, Amore A, Barratt J, Berthoux F, Bonsib S, Bruijn JA, D'Agati V, D'Amico G, Emancipator S, Emma F, Ferrario F, Fervenza FC, Florquin S, Fogo A, Geddes CC, Groene HJ, Haas M, Herzenberg AM, Hill PA, Hogg RJ, Hsu SI, Jennette JC, Joh K, Julian BA, Kawamura T, Lai FM, Leung CB, Li LS, Li PK, Liu ZH, Mackinnon B, Mezzano S, Schena FP, Tomino Y, Walker PD, Wang H, Weening JJ, Yoshikawa N\&Zhang H.(2009). Working Group of the International IgA Nephropathy Network and the Renal Pathology Society, The Oxford classification of IgA nephropathy: rationale, clinicopathological correlations, and classification. Kidney International, Vol.76, No.5 (September 2009), pp. 534-545, ISSN 0085-2538

Bellu SS, Troyanov, S, Hook T, Roberts ISD, on behalf of a Working Group of the International IgA Nephropathy Network and the Renal Pathology Society(2011). Immunostaining findings in $\operatorname{Ig} \mathrm{A}$ nephropathy: correlation with histology and clinical outcome in the Oxford classification patient cohort Nephrol Dial Transplant. doi: 10.1093/ndt/gfq812

Alchi B, Jayne D.(2010). Membranoproliferative glomerulonephritis. Pediatric Nephrology, Vol.25 No.8 (August 2010), pp 1409-1418, ISSN 0931-041X

Colucci G, Manno C, Grandaliano G, Schena FP. (2011). Cryoglobulinemic membranoproliferative glomerulonephritis: beyond conventional therapy. Clinical Nephrology, Vol. 74, No.4 (April 2010), pp. 374-379, ISSN 0301-0430

Nasr SH, Markowitz GS, Stokes MB, Said SM, Valeri AM, D'Agati VD.(2008). Acute postinfectious glomerulonephritis in the modern era: experience with 86 adults and review of the literature. Medicine (Baltimore), Vol.87, No.1 (January 2008), pp. 2132 ISSN 1048-9614

Wen YK, Chen ML.(2010). The significance of atypical morphology in the changes of spectrum of postinfectious glomerulonephritis. Clinical Nephrology, Vol. 73, No.3 (March 2010), pp. 173-179, ISSN 0301-0430

Silvariño R, Sant F, Espinosa G, Pons-Estel G, Solé M, Cervera R, Arrizabalaga P.(2011). Nephropathy associated with antiphospholipid antibodies in patients with systemic lupus erythematosus. Lupus, Vol.20, No.7 (2011), pp. 721-729, ISSN 09612033

Keir L, Coward RJ.(2011). Advances in our understanding of the pathogenesis of glomerular thrombotic microangiopathy. Pediatric Nephrology, Vol.26 No.4 (April 2011), pp 523-533, ISSN 0931-041X

Benz K, Amann K.(2010). Thrombotic microangiopathy: new insights. Current Opinion in Nephrology and Hypertension, Vol.19, No.3 (May 2010), pp. 242-247, ISSN 10624821

Kowalewska J, Nicosia RF, Smith KD, Kats A, Alpers CE.(2011). Patterns of glomerular injury in kidneys infiltrated by lymphoplasmacytic neoplasms. Human Pathology, Vol.42, No.6 (June 2011), pp. 896-903, ISSN 0046-8177

Simms RJ, Hynes AM, Eley L, Sayer JA.(2011). Nephronophthisis: a genetically diverse ciliopathy. International Journal of Nephrology, Vol. No. (2011), pp. ISSN

Wolf MT, Hildebrandt F.(2011). Nephronophthisis. Pediatric Nephrology, Vol.26 No.2 (February 2011), pp 181-194, ISSN 0931-041X 
Midgley JP, El-Kares R, Mathieu F, Goodyer P.(2011). Natural history of adolescent-onset cystinosis. Pediatric Nephrology, Vol.26 No.8 (August 2011), pp 1335-1337, ISSN 0931-041X

Chandra M, Stokes MB, Kaskel F.(2010). Multinucleated podocytes: a diagnostic clue to cystinosis. Kidney International, Vol.78, No.10 (November 2010), pp 1052, ISSN 0085-2538

Sun HJ, Zhou T, Wang Y, Fu YW, Jiang YP, Zhang LH, Zhang CB, Zhou HL, Gao BS, Shi YA, Wu S.(2011). Macrophages and T lymphocytes are the predominant cells in intimal arteritis of resected renal allografts undergoing acute rejection. Transplant Immunology, Vol.25, No.1 (July 2011), pp. 42-48, ISSN 0966-3274

John R, Herzenberg AM.(2010). Our approach to a renal transplant biopsy. Journal of Clinical Pathology, Vol.63, No.1, (January 2010), pp. 26-37, ISSN 0021-9746 


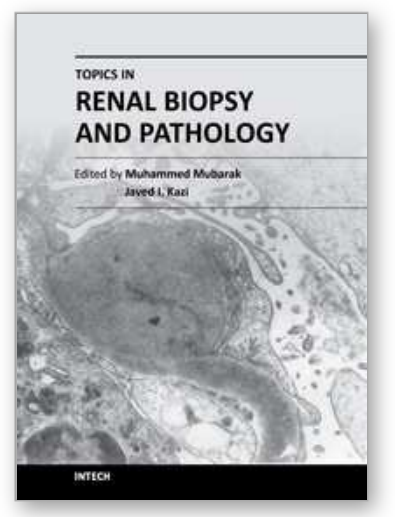

\author{
Topics in Renal Biopsy and Pathology \\ Edited by Dr. Muhammed Mubarak
}

ISBN 978-953-51-0477-3

Hard cover, 284 pages

Publisher InTech

Published online 04, April, 2012

Published in print edition April, 2012

There is no dearth of high-quality books on renal biopsy and pathology in the market. These are either single author or multi-author books, written by world authorities in their respective areas, mostly from the developed world. The vast scholarly potential of authors in the developing countries remains underutilized. Most of the books share the classical monotony of the topics or subjects covered in the book. The current book is a unique adventure in that it bears a truly international outlook and incorporates a variety of topics, which make the book a very interesting project. The authors of the present book hail not only from the developed world, but also many developing countries. The authors belong not only to US but also to Europe as well as to Pakistan and Japan. The scientific content of the book is equally varied, spanning the spectrum of technical issues of biopsy procurement, to pathological examination, to individual disease entities, renal graft pathology, pathophysiology of renal disorders, to practice guidelines.

\title{
How to reference
}

In order to correctly reference this scholarly work, feel free to copy and paste the following:

Şafak Güçer (2012). Diagnostic Algorithms in Renal Biopsy Interpretation Along with Case Samples, Topics in Renal Biopsy and Pathology, Dr. Muhammed Mubarak (Ed.), ISBN: 978-953-51-0477-3, InTech, Available from: http://www.intechopen.com/books/topics-in-renal-biopsy-and-pathology/diagnostic-algorithms-in-renalbiopsy-interpretation-with-case-samples

\section{INTECH}

open science | open minds

\author{
InTech Europe \\ University Campus STeP Ri \\ Slavka Krautzeka 83/A \\ 51000 Rijeka, Croatia \\ Phone: +385 (51) 770447 \\ Fax: +385 (51) 686166 \\ www.intechopen.com
}

\author{
InTech China \\ Unit 405, Office Block, Hotel Equatorial Shanghai \\ No.65, Yan An Road (West), Shanghai, 200040, China \\ 中国上海市延安西路65号上海国际贵都大饭店办公楼 405 单元 \\ Phone: +86-21-62489820 \\ Fax: +86-21-62489821
}


(C) 2012 The Author(s). Licensee IntechOpen. This is an open access article distributed under the terms of the Creative Commons Attribution 3.0 License, which permits unrestricted use, distribution, and reproduction in any medium, provided the original work is properly cited. 